\title{
A temporally and spatially resolved validation of emission inventories by measurements of ambient volatile organic compounds in Beijing, China
}

\author{
M. Wang ${ }^{1}$, M. Shao ${ }^{1}$, W. Chen ${ }^{1}$, B. Yuan ${ }^{1, *}$, S. Lu ${ }^{1}$, Q. Zhang ${ }^{2}$, L. Zeng ${ }^{1}$, and Q. Wang ${ }^{1,3}$ \\ ${ }^{1}$ State Joint Key Laboratory of Environmental Simulation and Pollution Control, College of Environmental \\ Sciences and Engineering, Peking University, Beijing, China \\ ${ }^{2}$ Ministry of Education Key Laboratory for Earth System Modeling, Center for Earth System Science, \\ Tsinghua University, Beijing, China \\ ${ }^{3}$ Beijing Municipal Environmental Monitoring Center, Beijing, China \\ *now at: NOAA Earth System Research Laboratory and Cooperative Institute for Research in Environmental \\ Sciences, University of Colorado, Boulder, CO, USA
}

Correspondence to: M. Shao (mshao@pku.edu.cn)

Received: 21 September 2013 - Published in Atmos. Chem. Phys. Discuss.: 16 October 2013

Revised: 14 January 2014 - Accepted: 26 February 2014 - Published: 16 June 2014

\begin{abstract}
Understanding the sources of volatile organic compounds (VOCs) is essential for ground-level ozone and secondary organic aerosol (SOA) abatement measures. We made VOC measurements at 27 sites and online observations at an urban site in Beijing from July 2009 to January 2012. Based on these measurement data, we determined the spatial and temporal distribution of VOCs, estimated their annual emission strengths based on their emission ratios relative to carbon monoxide ( $\mathrm{CO}$ ), and quantified the relative contributions of various sources using the chemical mass balance (CMB) model. These results from ambient measurements were compared with existing emission inventories to evaluate the spatial distribution, species-specific emissions, and source structure of VOCs in Beijing. The measured VOC distributions revealed a hotspot in the southern suburban area of Beijing, whereas current emission inventories suggested that VOC emissions were concentrated in downtown areas. Compared with results derived from ambient measurements, the annual inventoried emissions of oxygenated VOC (OVOC) species and $\mathrm{C} 2-\mathrm{C} 4$ alkanes may be underestimated, while the emissions of styrene and 1,3-butadiene may be overestimated by current inventories. Source apportionment using the CMB model identified vehicular exhaust as the most important VOC source, with the relative contribution of $49 \%$, in good agreement with the $40-51 \%$ estimated by emission
\end{abstract}

inventories. The relative contribution of paint and solvent utilization obtained from the CMB model was $14 \%$, significantly lower than the value of $32 \%$ reported by one existing inventory. Meanwhile, the relative contribution of liquefied petroleum gas (LPG) usage calculated using the CMB model was $6 \%$, whereas LPG usage contribution was not reported by current emission inventories. These results suggested that VOC emission strengths in southern suburban area of Beijing, annual emissions of $\mathrm{C} 2-\mathrm{C} 4$ alkanes, OVOCs and some alkenes, and the contributions of solvent and paint utilization and LPG usage in current inventories all require significant revisions.

\section{Introduction}

Volatile organic compounds (VOCs) play important roles in atmospheric chemistry because they can be photochemically oxidized to form ground-level ozone $\left(\mathrm{O}_{3}\right)$ and secondary organic aerosols (SOAs) (Seinfeld and Pandis, 2006). In Beijing and its surrounding areas, air pollution that is characterized by concurrent high ground-level $\mathrm{O}_{3}$ and fine particle $\left(\mathrm{PM}_{2.5}\right)$ concentrations has become a severe problem (Shao et al., 2009). Obtaining accurate knowledge on VOC emissions and sources is essential to understanding VOCs' roles 
in $\mathrm{O}_{3}$ and SOA formation and for the establishment of effective control measures to reduce ambient concentrations of these secondary pollutants.

VOCs can be directly emitted into the atmosphere from both natural and anthropogenic processes, and they may also be formed as products of the photochemical oxidation of other VOC species. On a global scale, natural emissions are the most important VOC sources, whereas anthropogenic emissions are dominant in most urban areas (Atkinson and Arey, 2003). The emission inventory can provide information on emission magnitudes, spatial and temporal distribution of emission strengths, and source structure for VOC species. The construction of an emission inventory is achieved using a "bottom-up" approach, summing the products of activity data and emission factors for all known individual sources. However, the establishment of an emission inventory for nonmethane VOCs (NMVOCs) is not only timeand resource-consuming but also plagued by large and inherent uncertainties due to the inaccurate and incomplete local knowledge of NMVOC emission characteristics (e.g., source profiles, emission factors) and source activities. Several studies have built anthropogenic VOC emission inventories in Beijing, and the annual NMVOC emissions are shown in Supplement Fig. S1 (Klimont et al., 2002; Streets et al., 2003; Ohara et al., 2007; Bo et al., 2008; Wei et al., 2008; Zhang et al., 2009; Zhao et al., 2012). Anthropogenic NMVOC emissions during 1990s, 2000s, and mid-2000s in Beijing from different inventories were consistent within the error bars. The largest discrepancy of NMVOC emission during mid-2000s exists between the inventories built by Bo et al. (2008) and Zhang et al. (2009), with a relative difference of $49 \%$. It should be noted that open biomass burning was included in the emission inventory built by Bo et al. (2008) but not in the INTEX-B inventory compiled by Zhang et al. (2009). Therefore, the discrepancy of NMVOC emission between these two inventories should be larger than that illustrated in Supplement Fig. S1. In addition, the spatial distribution of NMVOC emissions in Beijing reported by Zhang et al. (2009) illustrated that the largest emission strengths were in southern areas, whereas Zhao et al. (2012) suggested that NMVOC emissions were mainly concentrated in the downtown area. For the source structure of NMVOCs in Beijing, the four emission inventories listed in Table 1 all indicated that vehicular emission was the most important NMVOC source in Beijing, with the relative contributions in the range of $40-55 \%$. However, the relative contribution of paint and solvent utilization estimated by Wei et al. (2008) was $32 \%$, significantly higher than the value of $14 \%$ reported by Bo et al. (2008). The relative contributions of industrial and residential emissions reported by Zhang et al. (2009) and Zhao et al. (2012) also showed significant disagreements. Zhang et al. (2009) reported that industrial emissions contributed $41 \%$ of anthropogenic NMVOC emission in Beijing, whereas Zhao et al. (2012) estimated that the relative contribution of industrial emissions was only $3 \%$. In contrast with industrial emissions, the residential emissions contribution reported by Zhang et al. (2009) was $16 \%$, significantly lower than the value of $41 \%$ reported by Zhao et al. (2012). These comparisons among different emission inventories revealed the uncertainty of NMVOC emissions in Beijing. However, this comparison could not quantify the uncertainty, nor could it evaluate the accuracy of NMVOC emission inventories. An alternative method of proceeding is to use measurement data to evaluate and improve the degree of consistency between measurements and emission inventories, a technique that is often termed a "receptor-oriented" or "top-down" method. Since the measured concentration of NMVOCs is actually the result of emissions after physical (transport/mixing/deposition) and chemical transformations, various approaches need to be employed to build relationships between measurements and emissions.

Previous studies applied a tracer ratio method to estimate anthropogenic emissions of individual NMVOC species (Hsu et al., 2010; Shao et al., 2011; Yao et al., 2012). In this method, carbon monoxide (CO) is usually chosen as the reference tracer due to its long atmospheric lifetime $\left(k_{\mathrm{OH}}=1.4 \times 10^{-13} \mathrm{~cm}^{3}\right.$ molecule ${ }^{-1} \mathrm{~s}^{-1}$ ) (Atkinson et al., 2006) and its significant correlation with most anthropogenic VOC species (Baker et al., 2008; von Schneidemesser et al., $2010)$ in urban areas. Another reason for using CO as a reference tracer is that $\mathrm{CO}$ emission inventories in China have recently been validated based on measurement data, and thus $\mathrm{CO}$ emissions are relatively better understood than those of VOCs (Tang et al., 2013; Heald et al., 2003). However, the measured ratios of $\mathrm{VOC}$ species relative to $\mathrm{CO}(\mathrm{VOC} / \mathrm{CO})$ will change with photochemical processing because $\mathrm{CO}$ is less photochemically reactive than most VOC species and, furthermore, some carbonyl compounds may be photochemically produced. De Gouw et al. (2005) examined the oxidation of VOCs by $\mathrm{OH}$ radicals and developed two parameterization equations to describe the photochemical evolution of measured ratios of hydrocarbon/CO and carbonyl/CO. Based on these equations, the emission ratios for anthropogenic VOC species relative to $\mathrm{CO}$ can be derived from measured ratios (Warneke et al., 2007; Borbon et al., 2013). The anthropogenic emissions of VOC species can then be calculated based on the derived VOC emission ratios and the known emission for the reference compound (i.e., $\mathrm{CO}$ ).

Three-dimensional air quality models are increasingly being used to evaluate and validate VOC emission inventories through comparing simulated and observed concentrations. Coll et al. (2010) and Chen et al. (2010) compared VOC surface observations in Marseille (France) and Taiwan with regional-scale model simulations and found large differences between measurements and model outputs, indicating that emissions for many VOC species from inventories required corrections. Fu et al. (2007) and Liu et al. (2012a) applied inverse modeling techniques to constrain formaldehyde (HCHO) and glyoxal (CHOCHO) precursor emissions in China based on satellite observations. In the study by 
Table 1. Comparison of the relative contributions (\%) of anthropogenic sources of NMVOC emissions in Beijing calculated by the CMB model in this study and results from bottom-up emission inventories.

\begin{tabular}{|c|c|c|c|c|c|c|c|}
\hline Source categories & $\begin{array}{l}\text { CMB_M } \\
\text { this study, } 2\end{array}$ & CMB_E & $\begin{array}{c}\text { Wei et al. (2008) } \\
2005\end{array}$ & $\begin{array}{c}\text { Bo et al. (2008) } \\
2005\end{array}$ & Source categories & $\begin{array}{c}\text { Zhao et al. (2012) } \\
2003\end{array}$ & $\begin{array}{c}\text { Zhang et al. (2009) } \\
2006\end{array}$ \\
\hline Transportation & 46 & 49 & 40 & 51 & Transportation & 55 & 41 \\
\hline Industrial processing & 17 & 8 & 14 & 10 & Industry & $3^{\mathrm{e}}$ & $41^{\mathrm{e}}$ \\
\hline Paint and solvent utilization & 5 & 14 & 32 & 14 & Residential & 41 & 16 \\
\hline Fossil fuel combustion & $10^{\mathrm{c}}$ & $9^{c}$ & 3 & 15 & Others & 1 & 2 \\
\hline Petroleum storage and transport & $6^{\mathrm{d}}$ & $4^{\mathrm{d}}$ & - & 6 & & & \\
\hline LPG usage & 15 & 6 & - & - & & & \\
\hline Others & - & - & 11 & 4 & & & \\
\hline
\end{tabular}

a The relative contribution of each source category calculated by the CMB model based on measurement data (CMB_M) corresponds to the average value of CMB results of 824 samples collected at 27 sites in Beijing during July 2009 to January 2011. ${ }^{\text {b }}$ The relative contribution of each source category was calculated by the CMB model based on individual NMHC emissions (CMB_E). ${ }^{\mathrm{c}}$ The relative contributions of fossil fuel combustion reported by Bo et al. (2008) and Wei et al. (2008) were compared with that of coal combustion from the CMB model. ${ }^{\mathrm{d}}$ The relative contribution of petroleum storage and transport reported by Bo et al. (2008) was compared with that of gasoline evaporation from the CMB model. ${ }^{\text {e }}$ The relative contribution of industry reported by Zhang et al. (2009) and Zhao et al. (2012) also included NMVOC emissions from industrial solvent use besides industrial processing.

Fu et al. (2007), the total emission for HCHO precursors constrained based on observed HCHO columns was higher than that from the TRACE-P inventory built by Streets et al. (2003), and the VOC emissions from biomass/biofuel burning and biogenic sources were considered to be underestimated in the TRACE-P inventory. Liu et al. (2012a) found that the modeled CHOCHO columns based on the INTEX-B inventory were lower than satellite-observed values and suggested that this discrepancy was likely caused by the underestimation of aromatic emissions in the INTEX-B inventory.

Receptor models based on ambient measurements can calculate the relative contributions of various sources and thus can be used to evaluate the accuracy of VOC source structure from emission inventories (Fujita et al., 1995; Niedojadlo et al., 2007; Gaimoz et al., 2011). Recently, VOC source apportionment work has been intensively studied in Beijing using receptor models (Wang et al., 2010; Song et al., 2007; Shao et al., 2011). All of these studies showed that vehicular emission (in particular from gasoline-powered vehicles) was the main source of ambient nonmethane hydrocarbons (NMHCs) in Beijing, with relative contributions of 52-69\%. The relative contributions of vehicular emission in inventories built by Wei et al. (2008) and Zhang et al. (2009) were slightly lower than receptor model results, with values of 40$41 \%$. Besides the inherent uncertainties in both VOC emission inventories and receptor model results, another possible reason for this discrepancy is that the previous receptor modeling studies were based on measurement data obtained at limited sites (e.g., one or several urban sites) over short time periods (e.g., one month in summer), whereas emission inventories were generally established on an annual basis for the entire city. Therefore, more ambient city-scale measurements over annual intervals are required in order to compare VOC source structures between receptor models and emission inventories.

In this study, we first present the temporal and spatial distributions of VOCs in Beijing based on regional and online measurements from July 2009 to January 2012. Then, the emission ratios of individual VOC species relative to $\mathrm{CO}$ are determined in order to calculate the annual anthropogenic emissions for individual VOC species. Finally, the relative contributions of different sources to NMHC emissions are quantified using the chemical mass balance (CMB) receptor model. These results from ambient VOC measurements are compared with existing emission inventories to evaluate the accuracy of those inventories from the perspective of spatial distribution, annual emissions of individual VOC species, and relative contributions from various sources.

\section{Methods}

\subsection{VOC sampling and analysis}

\subsubsection{Online measurements of ambient VOCs at an urban site in Beijing}

Online measurements of ambient VOCs were conducted during summer (30 July to 20 September 2011) and winter (29 December 2011 to 18 January 2012) at the top of a six-story building on the Peking University campus in Beijing (the PKU site; $\left.40.00^{\circ} \mathrm{N}, 116.31^{\circ} \mathrm{E}\right)$. This site, which is located $10 \mathrm{~km}$ northwest of Beijing city center and about $200 \mathrm{~m}$ north of the fourth ring road, represents a typical urban environment in Beijing (Liu et al., 2009; Wang et al., 2010).

Ambient C2-C12 hydrocarbons, C3-C6 carbonyl compounds, $\mathrm{C} 1-\mathrm{C} 2$ halocarbons, and $\mathrm{C} 1-\mathrm{C} 4$ alkyl nitrates were measured using an online automated gas chromatography (GC) system, coupled with an ultralow temperature, cryogen-free preconcentration device. Detailed analytical methods and quality-assurance-quality-control (QAQC) procedures for this system have been described elsewhere (Wang et al., 2013; Yuan et al., 2012). Ambient formaldehyde and acetaldehyde were measured using a commercial high-sensitivity (HS) proton transfer reaction mass spectrometer (PTR-MS) (Ionicon Analytik, Innsbruck, Austria). The PTR-MS setup and QA-QC details were reported by Yuan et al. (2012). 
Ambient levels of $\mathrm{CO}, \mathrm{O}_{3}$, and $\mathrm{NO}_{\mathrm{x}}$ were measured using a commercial infrared filter correlation analyzer (Model 48i, TEI, USA), a UV photometric analyzer (Model 49i, TEI), and a chemiluminescence trace-level analyzer (Model 42iTL, TEI), respectively.

\subsubsection{Offline VOC measurements at 27 sites in Beijing}

Twenty-seven sampling sites were selected across Beijing to conduct regional VOC measurements (see the blue triangles in Fig. 1 and the site number in Supplement Table S1). These sites were grouped into five categories based on their geographic locations, prevailing monsoon wind directions, and proximity to major roadways (Supplement Table S1). The Urban, Suburban_South, Suburban_North, and Rural categories included sites located in the central downtown, southern suburbs, northern suburbs, and western rural areas of Beijing, respectively. Most sites were placed $\sim 3-$ $20 \mathrm{~m}$ above ground level in well-ventilated areas, such as parks and schools, to avoid the potential influences from local sources. The Roadside site category included three sites near roadways (R1-R3), which were designed to investigate the influences of traffic-related sources. When choosing sampling locations for VOC regional measurements in Beijing, the environmental automatic air quality monitoring stations were given priority in order to obtain simultaneous data for $\mathrm{NO}_{\mathrm{x}}$ and $\mathrm{O}_{3}$.

Sixteen sampling days from July 2009 to January 2011 were selected carefully to conduct VOC regional measurements. Most sampling campaigns were conducted on those days characterized by low wind speed, high relative humidity, and poor visibility. Ambient air samples were collected at 09:00 and 13:00 LT on each sampling day. Details of the sampling periods and meteorological parameters are summarized in Table S2 of the Supplement. The abnormal data that were obviously influenced by local sources were excluded from the following analyses in Sect. 3, and a total of 844 valid VOC data were obtained from regional measurements.

Ambient air was instantaneously sampled using $3.2 \mathrm{~L}$ fused silica stainless steel canisters (Entech Instruments, Simi Valley, CA, USA) that had been precleaned with highpurity nitrogen and evacuated with an Entech 3100 automated canister cleaner (Entech Instruments, USA). After sampling, these canisters were returned to the laboratory in Peking University within one week to analyze the target compounds using a three-stage cryofocusing preconcentration system (Entech 7100, Entech Instruments) coupled with a GC system (HP-7890A, Agilent Technologies, Santa Clara, CA, USA). The analytical methods and QA-QC procedures for the offline VOC measurement system were described in detail by Liu et al. (2008b) and Wang et al. (2010). The 55NMHC standard gas (Spectra Gases Inc., USA) was used to calibrate $\mathrm{C} 2-\mathrm{C} 12$ hydrocarbons. The method detection limits (MDLs) for C2-C12 hydrocarbons ranged from 0.009 to $0.057 \mathrm{ppbv}$.
Carbonyl compounds were measured at 27 sites in Beijing by in situ derivatization sampling using dinitrophenylhydrazine (DNPH)-coated silica cartridges (Agela Technologies, China) from July to September 2010 and in January 2011. Two ambient air samples were collected at a flow rate of $1 \mathrm{~L} \mathrm{~min}^{-1}$ through a potassium iodide (KI) ozone scrubber and a DNPH cartridge over two $3 \mathrm{~h}$ sampling periods on each sampling day (i.e., 09:00-12:00 LT and 13:00-16:00 LT). The sampled DNPH cartridges were stored at low temperature $\left(\sim 0{ }^{\circ} \mathrm{C}\right)$ and returned to our laboratory in Peking University. These cartridges were eluted with $5 \mathrm{~mL}$ acetonitrile, and then the target compounds were analyzed using highperformance liquid chromatography (HPLC), following the TO-11A procedures recommended by the US Environmental Protection Agency (EPA, Washington, DC, USA).

The CO levels in ambient air were quantified using an improved GC Flame Ionization Detector (FID) system with a home-built low-pressure injector. The air sample in the canister was first compressed to $1 \mathrm{~atm}$ and then each $10 \mathrm{~mL}$ aliquot was injected into the GC system (HP6890A, Hewlett Packard, USA) that used two molecularsieve-packed columns in series to separate $\mathrm{CO}$ and methane. The first column with length of $1.8 \mathrm{~m}$ was filled with $5 \AA$ particles, while the second one with length of $2 \mathrm{~m}$ was packed with TDX01. During this analysis cycle, the GC system was operated isothermally at a column temperature of $105^{\circ} \mathrm{C}$. The column elutes were allowed to pass through a methane reformer using nickel as a catalyst, operated at $400^{\circ} \mathrm{C}$, to convert CO into methane, which was subsequently detected by the FID. Details of this system were provided in $\mathrm{Wu}$ et al. (2010).

Ambient $\mathrm{O}_{3}, \mathrm{NO}$, and $\mathrm{NO}_{2}$ data were obtained from automatic air monitoring stations operated by the Beijing Municipal Environment Monitoring Center.

\subsection{Receptor model}

The chemical mass balance model (CMB version 8.2), which was developed by the US EPA, was used to conduct VOC source apportionment. The relative contributions from various sources were estimated based on the source profiles for each source and the chemical speciation of ambient samples using the following mass balance equation:

$c_{i}=\sum_{j=1}^{J} \alpha_{i j} S_{j}(i=1,2, \ldots, I)$,

where $c_{i}$ is the ambient mass concentration of compound $i$ measured at receptor sites $\left(\mu \mathrm{g} \mathrm{m}^{-3}\right), \alpha_{i j}$ is the mass percentage of compound $i$ in an emission source $j, S_{j}$ is the contribution of source $j$ to the ambient sample, and $I$ and $J$ are the number of compounds and sources, respectively.

Ambient VOC concentrations and source profiles are two necessary inputs for the CMB modeling. In this study, four VOC data sets were inputted into the CMB model to calculate relative contributions of each source, including the 


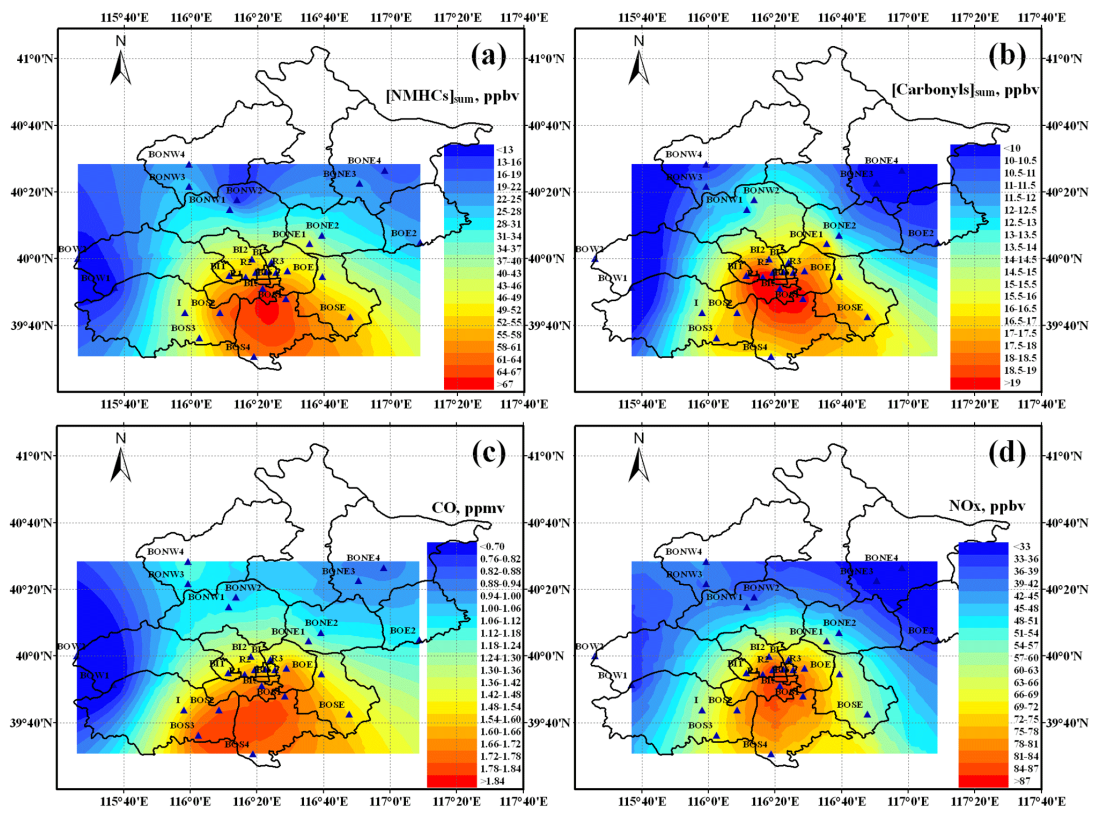

Figure 1. Contour maps of annual average mixing ratios of (a) total NMHCs, (b) total carbonyls, (c) CO, and (d) $\mathrm{NO}_{\mathrm{x}}$ at 27 sites in Beijing. Blue triangles indicate sampling locations. The names and typologies of these sites are listed in Supplement Table S1.

16-month regional measurements at 27 sites in Beijing, the online measurements at the PKU site during summer and winter of 2011, and the annual emissions for NMHC species derived from measurements. The data number $(N)$ of these VOC data sets for the CMB application in this study is summarized in Supplement Table S4. For the three measurement data sets, eight emission profiles were inputted into the $\mathrm{CMB}$ model, including biogenic emission, gasoline vehicle exhaust (Exhaust_G), diesel vehicle exhaust (Exhaust_D), coal combustion, gasoline evaporation (Gasoline), liquefied petroleum gas (LPG) usage, paint and solvent utilization (Paint and solvent), and industrial processing (Industry). For the VOC emission data set, only the seven anthropogenic sources were involved in CMB modeling. The source profiles used in this work were measured in China (Liu et al., 2008a).

The fitting species for the CMB modeling using measurement data were selected based on the following criteria: (1) they are major constituents of ambient samples and source emissions and (2) their atmospheric lifetime is longer than that of toluene (i.e., more reactive VOC species, such as alkenes and C8-C9 aromatics, were not included). Consequently, 25 VOC species were selected as fitting species, including C2-C9 alkanes, acetylene, benzene, toluene, and isoprene (shown in Supplement Table S3). Isoprene was applied as a fitting species for CMB modeling based on measurement data even though it is more reactive than toluene, because isoprene is the only tracer for biogenic emission. For the CMB modeling based on individual NMHC emissions, the fitting species also involved some reactive NMHC species, such as ethene, propene, ethylbenzene, and xylenes (shown in Supplement Table S3).

\section{Results and discussion}

\subsection{Spatial distribution of VOC mixing ratios}

The regional measurements in Beijing were conducted during periods with wind speeds $<1.5 \mathrm{~m} \mathrm{~s}^{-1}$, and therefore the spatial distribution of measured VOC mixing ratios could to some extent reflect the spatial patterns of VOC emission strengths. Based on the annual average mixing ratios of trace gases at each site, the universal Kriging method was applied to predict contour plots of [NMHCs] $]_{\text {sum }}$ (i.e., the summed mixing ratios of $53 \mathrm{C} 2-\mathrm{C} 10$ hydrocarbons; see Table S5 of the Supplement), [Carbonyls] $]_{\text {sum }}$ (i.e., the summed mixing ratios of eight C1-C6 carbonyl compounds; see Supplement Table S5), CO, and $\mathrm{NO}_{\mathrm{x}}$ levels in Beijing (Fig. 1a-d).

The measured $[\mathrm{NMHCs}]_{\text {sum }}$, [Carbonyls $]_{\text {sum }}, \mathrm{CO}$, and $\mathrm{NO}_{\mathrm{x}}$ levels displayed similar spatial patterns, with the highest mixing ratios in central (urban) and southern areas of Beijing. However, the emission inventories reported by Tang et al. (2010) and Wang et al. (2009) suggested that NMVOC and $\mathrm{NO}_{\mathrm{x}}$ emissions in Beijing were concentrated in downtown areas, with emission strengths that exceeded those in suburban areas by factors of $\sim 5-20$. It should be noted that the NMVOC emission inventories reported by Wang et al. (2009) and Tang et al. (2010) were established based on activity data collected in the years 2000 and 2006, respectively, whereas our measurements were conducted during 2009-2012. During the last two decades, the spatial distribution of industry in Beijing has been evolving. High pollution industries have gradually moved out of the urban center of Beijing; meanwhile, industrial clusters have been developed 
in suburban areas (Beijing Municipal Commission of Economy and Information Technology, http://www.bjeit.gov.cn/). The Beijing Economic-Technological Development Area (BDA), one of the fast-growing industrial zones that is located in the southern area of Beijing (see the BOS1 site in Fig. 1), contributed $16.3 \%$ of Beijing's total industrial production in 2010 (Beijing Municipal Bureau of Statistics, http: //www.bjstats.gov.cn/). Accompanied by the rapid economic development, southern suburban areas of Beijing have become more urbanized during recent years. As a result of the spatial changes in industry and urbanization level, hotspots of anthropogenic pollutant emissions have potentially extended into southern suburban areas of Beijing. The differences in anthropogenic NMVOC spatial distribution between measurements and emission inventories indicates that these emission inventories may not accurately reflect the current spatial distribution of NMVOC emissions in Beijing. Therefore, an updated NMVOC emission inventory for Beijing with a high spatial resolution is urgently needed in order to gain a better understanding regarding regional pollution with $\mathrm{O}_{3}$ and SOA based on chemical transport models.

\subsection{Temporal variations in VOC speciation}

The chemical composition of ambient VOCs can be affected by the relative contributions of various VOC emission sources and photochemical and mixing processes during transport. In this section, the monthly variations in some representative VOC ratios were examined to investigate seasonal variations of VOC sources and photochemistry. Figure 2ac shows seasonal variations in the ratios of $i$-pentane to acetylene, toluene to ethene, and isoprene to 1,3-butadiene. The reactivity for the two compounds of these hydrocarbon pairs was similar, but their emission sources showed significant differences. Vehicular exhaust was found to be the dominant source of acetylene, ethene, and 1,3-butadiene in Beijing (Wang et al., 2010), while $i$-pentane, toluene, and isoprene were also influenced by gasoline evaporation (Liu et al., 2008a), solvent and paint utilization (Liu et al., 2008a; Yuan et al., 2010a), and biogenic emissions (Fuentes et al., 1996), respectively. The ratios of $i$-pentane/acetylene and toluene/ethene both exhibited higher values in summer than in winter (Fig. 2a and b) because the high ambient temperatures in summer could increase the evaporation rate of VOCs from gasoline and paint. Ambient levels of isoprene and 1,3-butadiene showed a significant correlation $\left(r^{2}=0.56\right)$ in winter (November-March), with the average ratio of $0.29 \mathrm{ppbv} \mathrm{ppbv}^{-1}$. The calculated wintertime ratio for isoprene/1,3-butadiene in Beijing was close to the values of $0.30-0.34 \mathrm{ppbv} \mathrm{ppbv}^{-1}$ for vehicular exhaust reported by Borbon et al. (2001) in France and Wang et al. (2010) in Beijing, indicating that vehicular exhaust was the dominant source of atmospheric isoprene during winter. However, measured ratios of isoprene/1,3-butadiene from May to September were $16-43 \mathrm{ppbv} \mathrm{ppbv}^{-1}$, higher than wintertime ratios by factors $>50$ (Fig. 3c), indicating that biogenic emissions dominated summertime isoprene. Figure $2 \mathrm{~d}$ shows the monthly variation in the measured ratios of ethene to acetylene. These two species are both mainly emitted from combustion sources (Wang et al., 2010), but they have different atmospheric lifetimes (Atkinson et al., 2006), and therefore the variation in their ratios may reflect the photochemical degrees of sampled air masses. The ratios of ethene/acetylene from June to October were $0.6-0.8 \mathrm{ppbv} \mathrm{ppbv}^{-1}$, significantly lower than the ratios from November to March (1.0$1.5 \mathrm{ppbv} \mathrm{ppbv}^{-1}$ ), indicating the important influence of photochemistry on the chemical composition of VOCs during summer.

To further investigate the effect of photochemistry on the chemical composition of VOCs during summer, the average diurnal profiles for measured ratios of benzene, trans-2-pentene, 2-butyl nitrate $\left(2-\mathrm{BuONO}_{2}\right)$, and acetaldehyde to acetylene at the PKU site were examined (Fig. 3). The atmospheric lifetime for benzene $\left(k_{\mathrm{OH}}=1.2 \times 10^{-12} \mathrm{~cm}^{3}\right.$ molecule $\left.{ }^{-1} \mathrm{~s}^{-1}\right)$ is similar to that for acetylene $\left(k_{\mathrm{OH}}=1.0 \times 10^{-12} \mathrm{~cm}^{3}\right.$ molecule $\left.\mathrm{s}^{-1} \mathrm{~s}^{-1}\right)$, and therefore the ratios of benzene/acetylene exhibited relatively flat diurnal variations (Fig. 3a). Unlike benzene/acetylene, the measured ratios of trans-2pentene/acetylene exhibited a significant decrease during the morning ( 05:00-09:00 LT), since trans-2-pentene $\left(k_{\mathrm{OH}}=6.7 \times 10^{-11} \mathrm{~cm}^{3}\right.$ molecule $\left.\mathrm{s}^{-1} \mathrm{~s}^{-1}\right)$ was photochemically removed more rapidly than acetylene. In contrast to the average diurnal profile for trans-2-pentene/acetylene, the measured ratios for $2-\mathrm{BuONO}_{2} /$ acetylene and acetaldehyde/acetylene both exhibited a significant increase from 07:00 LT until they reached maximum values in the afternoon ( 13:00-16:00 LT), indicating the strong photochemical production of these species during summer daytime hours. These findings suggest that photochemistry is another important factor influencing atmospheric VOC ratios besides the differences of VOC chemical composition between various sources. Therefore, the photochemical removal or production of VOCs must be considered and excluded when determining VOC emission characteristics from measurement data (Warneke et al., 2007; Borbon et al., 2013).

\subsection{Annual anthropogenic emissions of VOC species}

The anthropogenic emissions of VOC species can be estimated based on their emission ratios to a reference compound and the known emissions for the reference compound. The emission ratio for VOC species was defined as the ratio of VOC to a reference compound in fresh emissions without undergoing photochemical processing. However, as shown in the discussion of seasonal and diurnal variations of VOC ratios (Sect. 3.2), photochemical processing is an important influencing factor of VOC chemical compositions in ambient air. Therefore, the determination of VOC emission ratios from measurement data include two important steps: 

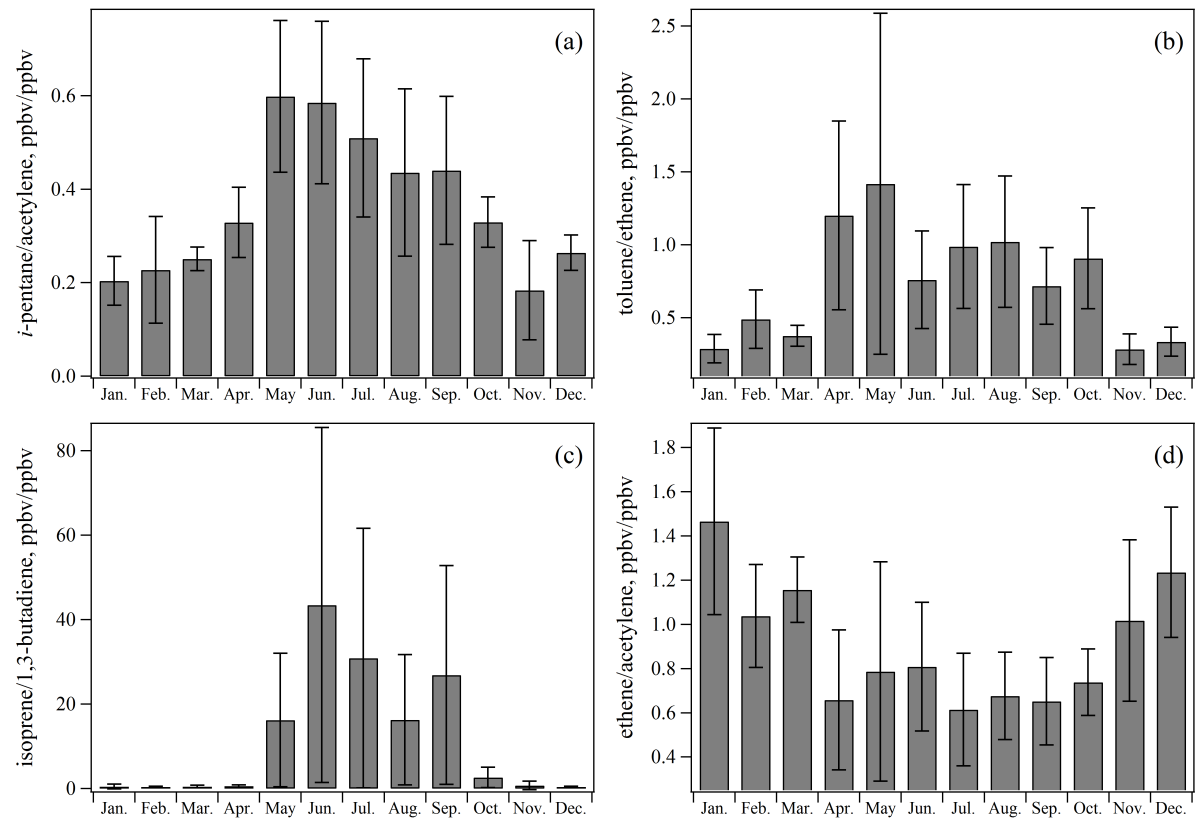

Figure 2. Monthly variations in the average ratios of (a) $i$-pentane to acetylene, (b) toluene to ethene, (c) isoprene to 1,3-butadiene, and (d) ethene to acetylene at urban sites in Beijing. Error bars represent one standard deviation from the mean ratios calculated at the 27 measuring sites.
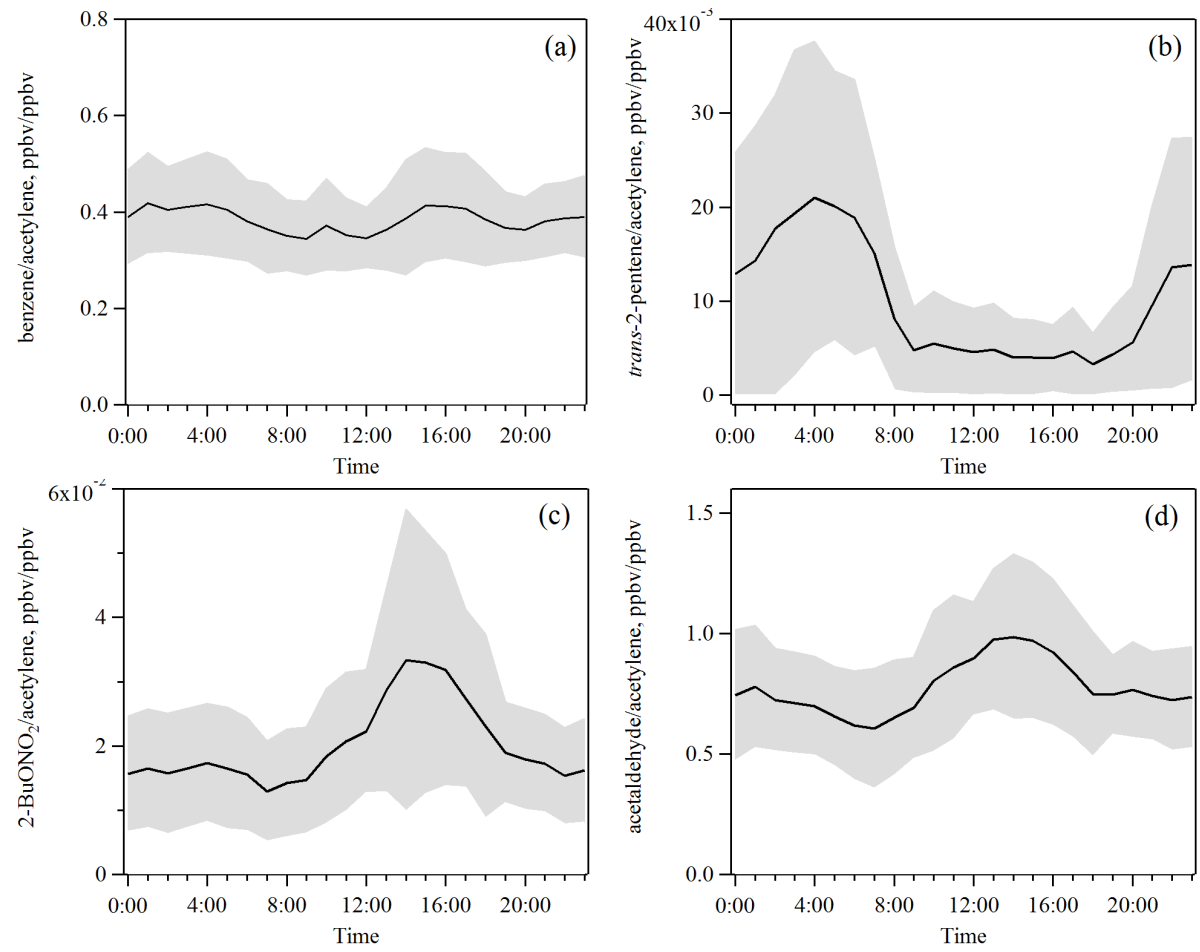

Figure 3. Diurnal variations in hourly average ratios of (a) benzene/acetylene, (b) trans-2-pentene/acetylene, (c) $2-\mathrm{BuONO}_{2} / \mathrm{acetylene}$, and (d) acetaldehyde/acetylene, measured during August-September 2011 at the PKU site. Grey areas represent one standard deviation from the hourly average ratio. 
(1) the selection of a suitable reference compound and (2) the derivation of $\mathrm{VOC}$ emission ratios from measured ratios, excluding or correcting the effect of photochemical processing on measured VOC ratios.

\subsubsection{Selection of a reference compound}

The selection of a reference compound for anthropogenic VOC species should consider the following criteria: (1) the reference compound should have similar sources with anthropogenic VOC, and (2) the uncertainty of its emissions should be lower than that of VOC emissions. In this study, we selected $\mathrm{CO}$ as the reference compound for the following reasons. For one, photochemical removal of $\mathrm{CO}$ can be neglected due to its low reactivity $\left(k_{\mathrm{OH}}=1.4 \times 10^{-3} \mathrm{~cm}^{3}\right.$ molecule $\left.{ }^{-1} \mathrm{~s}^{-1}\right)$. Secondly, previous studies on VOC sources suggested that vehicular emission was the dominant source in Beijing, with a relative contribution of $>40 \%$ (Wang et al., 2010; Zhang et al., 2009; Song et al., 2007). Emissions of CO, a product of the incomplete combustion of fuels, are also dominated by vehicular emission in urban areas (Baker et al., 2008; Parrish, 2006; von Schneidemesser et al., 2010). Additionally, the CO emission of Beijing during 2010 has been validated based on CO measurement data (Tang et al., 2013). The uncertainty in CO emission reported by Tang et al. (2013) was $\pm 46 \%$, significantly lower than the VOC emissions uncertainty of $\pm 130 \%$ reported by Streets et al. (2003) and $\pm 68 \%$ reported by Zhang et al. (2009).

Previous studies suggested that VOC emissions in Beijing could be influenced by noncombustion anthropogenic sources (e.g., gasoline evaporation, paint and solvent utilization), even though vehicular exhaust was the dominant source (Wang et al., 2010). Therefore, to further check the rationality of selecting $\mathrm{CO}$ as the reference compound, correlations between mixing ratios of individual VOC species and $\mathrm{CO}$ levels were analyzed. All anthropogenic VOC species showed significant correlations with $\mathrm{CO}$ in Beijing both in summer and winter at the 0.01 level (two-tailed), even for ethane and propane that were usually used as tracers of natural gas (NG) leakage (Katzenstein et al., 2003) and LPG usage (Blake and Rowland, 1995). Furthermore, the $r^{2}$ values for correlations between NMHC species and $\mathrm{CO}$ during summer were found to decrease with the rising of NMHC reactivity. Acetylene, ethane, propane, and benzene had the strongest correlations with $\mathrm{CO}\left(r^{2}>0.70\right)$, whereas $\mathrm{C} 8-\mathrm{C} 9$ aromatics and $\mathrm{C} 4-\mathrm{C} 5$ alkenes showed the weakest correlations with $\mathrm{CO}\left(r^{2}=0.17-0.53\right)$. Carbonyl compounds also showed relatively weak correlations with $\mathrm{CO}$, with $r^{2}$ in the range of $0.23-0.45$. This may be because reactive NMHC can be photochemically removed more rapidly than $\mathrm{CO}$, while carbonyls can be produced during photochemical processing.
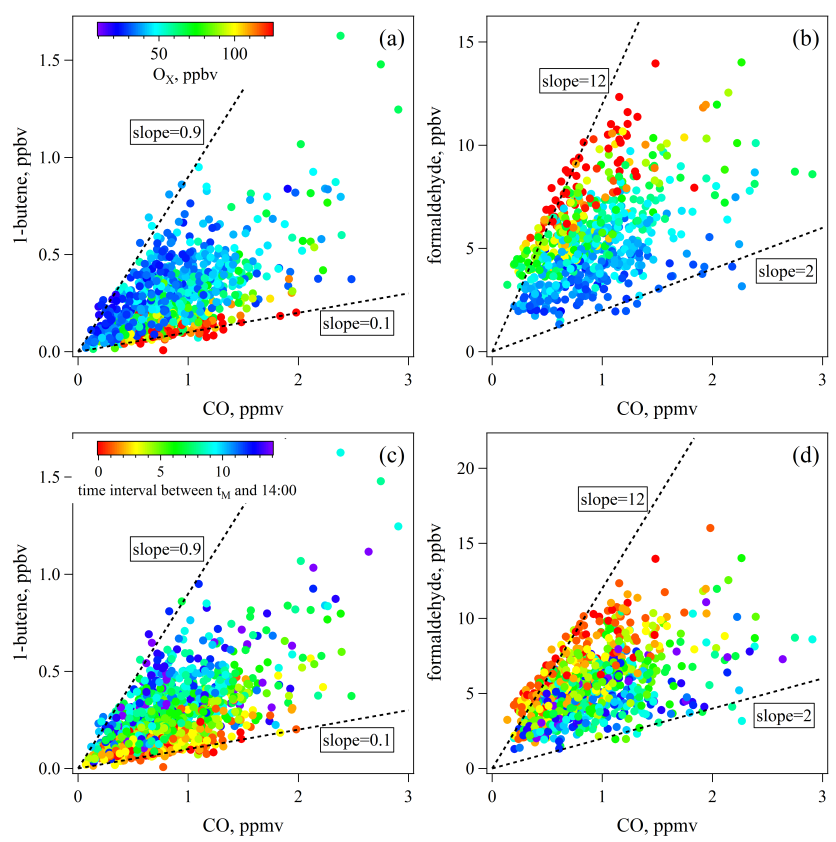

Figure 4. Scatter plots of (a, c) 1-butene and (b, d) formaldehyde vs. CO measured at the PKU site during August-September 2011. Data points in (a) and (b) were colored according to $\mathrm{O}_{\mathrm{x}}\left(\mathrm{O}_{3}+\mathrm{NO}_{2}\right)$ levels, while data points in (c) and (d) were colored according to time intervals between measurement time $\left(t_{\mathrm{M}}\right)$ and 14:00 LT.

\subsubsection{Derivation of emission ratios for individual VOC species}

Figure $4 \mathrm{a}-\mathrm{b}$ shows scatter plots of measured mixing ratios of 1-butene and formaldehyde vs. CO levels at the PKU site during August-September 2011, which were color-coded by total oxidant (i.e., $\mathrm{O}_{\mathrm{x}}=\mathrm{NO}_{2}+\mathrm{O}_{3}$ ) levels. It can be found that the measured ratios of 1-butene/CO decreased, but formaldehyde/CO increased with rising $\mathrm{O}_{\mathrm{x}}$ levels. Additionally, to investigate the daily variations of 1-butene/CO and formaldehyde/CO with time, the scatter plots of 1-butene and formaldehyde vs. $\mathrm{CO}$ were also color-coded by time intervals between measurement time $\left(t_{\mathrm{M}}\right)$ and 14:00 LT when the maximum $1 \mathrm{~h}$ average $\mathrm{O}_{\mathrm{x}}$ levels occurred (Fig. $4 \mathrm{c}$ and d). The highest 1-butene/CO and the lowest formaldehyde/CO ratios were measured during the night and early morning, suggesting the significant influence of photochemical processing on measured ratios of $\mathrm{VOC} / \mathrm{CO}$ during daytime.

In this study, emission ratios (ERs) for individual VOC species relative to $\mathrm{CO}$ were determined using two approaches from measurement data. The first method is to derive the slope of VOC mixing ratios to $\mathrm{CO}$ levels using a linear, two-sided least-square fit (the orthogonal distance regression (ODR) linear fit method) to the filtered observations, with the y-intercept allowed to vary (Warneke et al., 2007; Borbon et al., 2013). In this study, the temporal filter for the calculation of VOC emission ratios by the ODR linear fit method 
was selected based on the diurnal variation of not only photochemical processing extents but also measured VOC mixing ratios. The period 03:00-07:00 LT was selected as the temporal filter for online measurement data at the PKU site, due to the lowest photochemical degrees and the highest NMHC mixing ratios during this period. The calculated ratios for nonreactive NMHC species (e.g., ethane, propane, $n$-butane, benzene, and acetone) relative to $\mathrm{CO}$ from 03:00 to 07:00 LT data and all measurement data agreed well (Supplement Fig. S2), suggesting that VOC emission ratios during daytime and nighttime did not show significant changes. For regional measurements in Beijing and 47 cities in China, the observation data at 09:00 LT were used to calculate VOC emission ratios.

The other approach is based on the photochemical evolution of measured $\mathrm{VOC} / \mathrm{CO}$ ratios with air-mass aging (the $[\mathrm{OH}] \Delta t$ method), a method first introduced by de Gouw et al. (2005), followed by Warneke et al. (2007) and Borbon et al. (2013). In this method, the photochemical removal of VOC species is assumed to be dominated by a reaction with the $\mathrm{OH}$ radical. The photochemical evolution of measured ratios of hydrocarbon ( $\mathrm{HC}$ ) with $\mathrm{CO}$ can be described by the following equation:

$$
\frac{[\mathrm{HC}]}{[\mathrm{CO}]}=\mathrm{ER}_{\mathrm{HC}} \times \exp \left(\left(k_{\mathrm{CO}}-k_{\mathrm{HC}}\right)[\mathrm{OH}] \Delta t\right),
$$

where $[\mathrm{HC}] /[\mathrm{CO}]$ is the measured ratio of a particular hydrocarbon $\mathrm{HC}$ to $\mathrm{CO}, \mathrm{ER}_{\mathrm{HC}}$ is the emission ratio of $\mathrm{HC}$ to $\mathrm{CO}$, and $k_{\mathrm{HC}}$ and $k_{\mathrm{CO}}$ are the rate constants for the oxidation of $\mathrm{HC}$ and $\mathrm{CO}$ by the $\mathrm{OH}$ radical, respectively. The $\mathrm{OH}$ exposure $([\mathrm{OH}] \Delta t)$ is defined as the integral of atmospheric $\mathrm{OH}$ abundance extending from the time of emission $\left(t_{\mathrm{E}}\right)$ to the time of measurement $\left(t_{\mathrm{M}}\right)$. The derivation of oxygenated VOC (OVOC) emission ratios from ambient measurements is more complicated due to their photochemical production and the possible influences from biogenic sources and background concentrations. De Gouw et al. (2005) developed a multivariable regression method to calculate OVOC emission ratios as follows:

$$
\begin{aligned}
& {[\mathrm{OVOC}]=\mathrm{ER}_{\mathrm{OVOC}}} \\
& \times[\mathrm{CO}] \times \exp \left(-\left(k_{\mathrm{OVOC}}-k_{\mathrm{CO}}\right)[\mathrm{OH}] \Delta t\right) \\
& +\mathrm{ER}_{\text {precursors }} \times[\mathrm{CO}] \times \frac{k_{\text {precursors }}}{k_{\mathrm{OVOC}}-k_{\text {precursors }}} \\
& \times \frac{\exp \left(-k_{\text {precursors }}[\mathrm{OH}] \Delta t\right)-\exp \left(-k_{\mathrm{OVOC}}[\mathrm{OH}] \Delta t\right)}{\exp \left(k_{\mathrm{CO}}[\mathrm{OH}] \Delta t\right)} \\
& +([\text { biogenic }]+[\text { background }]),
\end{aligned}
$$

where $\mathrm{ER}_{\mathrm{OVOC}}$ and $\mathrm{ER}_{\text {precursors }}$ are the emission ratios of OVOC and their anthropogenic precursors, respectively. In Eq. (3), the first and second terms represent the photochemical removal of OVOC species from primary emissions and the secondary production by anthropogenic precursor oxidation, respectively. The [biogenic] term represents OVOC levels from biogenic emissions or produced by biogenic NMHC oxidation. The [background] term means the background mixing ratios for OVOC species.

In the latter method, determining the extent of photochemical aging of air masses (i.e., $\mathrm{OH}$ exposure) is the basis of deriving VOC emission ratios. The $\mathrm{OH}$ exposure can be calculated based on measured ratios of two hydrocarbons with similar sources but different lifetimes, using the following equation:

$$
\begin{aligned}
{[\mathrm{OH}] \Delta t } & =\frac{1}{k_{\mathrm{HC}_{1}}-k_{\mathrm{HC}_{2}}} \\
& \times\left(\ln \left(\frac{\left[\mathrm{HC}_{1}\right]_{0}}{\left[\mathrm{HC}_{2}\right]_{0}}\right)-\ln \left(\frac{\left[\mathrm{HC}_{1}\right]}{\left[\mathrm{HC}_{2}\right]}\right)\right),
\end{aligned}
$$

where $\left[\mathrm{HC}_{1}\right] /\left[\mathrm{HC}_{2}\right]$ is the measured ratio of $\mathrm{HC}_{1}$ to $\mathrm{HC}_{2}$ and $\left[\mathrm{HC}_{1}\right]_{0} /\left[\mathrm{HC}_{2}\right]_{0}$ is the emission ratio of $\mathrm{HC}_{1}$ to $\mathrm{HC}_{2}$. The value for $\left[\mathrm{HC}_{1}\right]_{0} /\left[\mathrm{HC}_{2}\right]_{0}$ is estimated as the highest average ratio of $\mathrm{HC}_{1} / \mathrm{HC}_{2}$ during the nighttime based on its diurnal variation profile (see the blue dashed line in Fig. 5a). Another method to determine $\mathrm{OH}$ exposure is based on the sequential reaction model $(\mathrm{SRM})$ of alkyl nitrates $\left(\mathrm{RONO}_{2}\right)$ developed by Bertman et al. (1995):

$$
\begin{aligned}
{[\mathrm{OH}] \Delta t } & =\frac{[\mathrm{OH}]}{k_{\mathrm{A}}-k_{\mathrm{B}}} \times\left(\ln \left(\frac{\left[\mathrm{RONO}_{2}\right]}{[\mathrm{RH}]}-\frac{\beta k_{\mathrm{A}}}{k_{\mathrm{B}}-k_{\mathrm{A}}}\right)\right. \\
& \left.-\ln \left(\frac{\left[\mathrm{RONO}_{2}\right]_{0}}{[\mathrm{RH}]_{0}}-\frac{\beta k_{\mathrm{A}}}{k_{\mathrm{B}}-k_{\mathrm{A}}}\right)\right),
\end{aligned}
$$

where $k_{\mathrm{A}}=k_{\mathrm{RH}}[\mathrm{OH}]$ and $k_{\mathrm{B}}=k_{\mathrm{RONO}_{2}}[\mathrm{OH}]+J_{\mathrm{RONO}_{2}}$ are the pseudo-first-order rate constants for the production and destruction of $\mathrm{RONO}_{2}$, respectively. $k_{\mathrm{RONO}_{2}}$ and $k_{\mathrm{RH}}$ are the rate constants for reactions of $\mathrm{RONO}_{2}$ and its parent alkane (RH) with the $\mathrm{OH}$ radical, respectively. $J_{\mathrm{RONO}_{2}}$ is the photolysis rate of $\mathrm{RONO}_{2}$, the values of which were taken from Bertman et al. (1995). [OH] is the average abundance of ambient $\mathrm{OH}$ radical from emission time to measurement time, which was assumed to be $5 \times 10^{6}$ and $1 \times 10^{6}$ molecule $\mathrm{cm}^{-3}$ in summer and winter, respectively, according to the measured and modeled $\mathrm{OH}$ abundances in Beijing (Takegawa et al., 2009; Liu et al., 2012b; Lu et al., 2013). The factor $\beta$ is the fraction ratio of $\mathrm{RONO}_{2}$ production from the reaction of $\mathrm{RH}$ with the $\mathrm{OH}$ radical, the values of which were taken from Kwok and Atkinson (1995). The $\left[\mathrm{RONO}_{2}\right]_{0} /[\mathrm{RH}]_{0}$ ratio is the initial ratio of $\mathrm{RONO}_{2}$ with $\mathrm{RH}$ at the emission time without undergoing photochemical processing; this was estimated to be the average ratio of $\left[\mathrm{RONO}_{2}\right] /[\mathrm{RH}]$ during nighttime (see the blue dashed line in Fig. 5b). The values of rate constants for VOC species with the $\mathrm{OH}$ radical were all taken from Atkinson et al. (2006).

In this study, the ratios of $o$-xylene to ethylbenzene $(\mathrm{X} / \mathrm{E})$ and $2-\mathrm{BuONO}_{2}$ to $n$-butane were selected to estimate $\mathrm{OH}$ exposure $\left([\mathrm{OH}] \Delta t_{\mathrm{X} / \mathrm{E}}\right.$ and $\left.[\mathrm{OH}] \Delta t_{\mathrm{AN}}\right)$ using Eqs. (4) and (5), respectively. The $\mathrm{X} / \mathrm{E}$ ratio was chosen to investigate the age of urban air masses for the following reasons: (1) xylenes and ethylbenzene have similar 

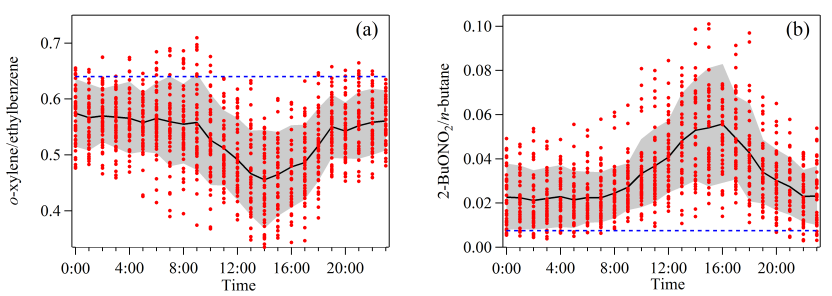

Figure 5. Diurnal variations in hourly average ratios of (a) $o$ xylene/ethylbenzene (X/E) and (b) $2-\mathrm{BuONO}_{2} / n$-butane measured during August-September 2011 at the PKU site. The red dots correspond to the measured ratios. The grey areas represent one standard deviation from the hourly average ratios. The blue dashed line corresponds to the average ratio at the time of emission $\left(t_{\mathrm{E}}\right)$.

sources and their emission ratios from different sources remain persistent (Monod et al., 2001), and therefore the measured $\mathrm{X} / \mathrm{E}$ ratios were mainly influenced by photochemical processing; (2) the atmospheric lifetime of $o$-xylene $\quad\left(k_{\mathrm{OH}}=13.7 \times 10^{-12} \mathrm{~cm}^{3}\right.$ molecule $\left.^{-1} \mathrm{~s}^{-1}\right)$ is significantly shorter than that of ethylbenzene $\left(k_{\mathrm{OH}}=7.1 \times 10^{-12} \mathrm{~cm}^{3}\right.$ molecule $\left.{ }^{-1} \mathrm{~s}^{-1}\right)$; (3) the ambient levels of ethylbenzene and $o$-xylene in Beijing were significantly higher than the detection limits of VOC analysis systems. The ratio of $2-\mathrm{BuONO}_{2} / n$-butane was selected to calculate $\mathrm{OH}$ exposure using the SRM method, since $2-\mathrm{BuONO}_{2}$ was the most abundant $\mathrm{RONO}_{2}$ species in China (Wang et al., 2013) and 2-butyl peroxy radical was believed to be mainly produced by the $\mathrm{OH}$ oxidation of $n$-butane (Bertman et al., 1995).

Figure $6 \mathrm{a}-\mathrm{b}$ compares the summertime emission ratios for individual VOC species calculated using the $[\mathrm{OH}] \Delta t$ method and the ODR linear fit method at the PKU site. The VOC emission ratios calculated based on the $[\mathrm{OH}] \Delta t_{\mathrm{X} / \mathrm{E}}$ and $[\mathrm{OH}] \Delta t_{\mathrm{AN}}$ correlated well $(r=0.997)$, with a linear regression slope of 1.08. The VOC emission ratios from the ODR linear fit method generally agreed with values from the $[\mathrm{OH}] \Delta t$ method within a factor of two. However, the emission ratios for some OVOC species (e.g., propanal, methyl ethyl ketone (MEK)) were overestimated, but the ERs for some reactive alkenes (e.g., propene, trans-2-butene, and 1,3-butadiene) were underestimated by the ODR linear fit method. This is possibly due to the influences from OVOC photochemical production and reactive alkene photochemical removal. In the following sections, the VOC emission ratios calculated based on the $[\mathrm{OH}] \Delta t_{\mathrm{AN}}$ were used to compare with other studies and to calculate annual emissions of VOC species in Beijing.

\subsubsection{Temporal variations in VOC emission ratios at the PKU site}

Figure 7a compares the derived emission ratios of VOC species relative to $\mathrm{CO}$ at the PKU site during summer and winter. The wintertime emission ratios for most VOC species
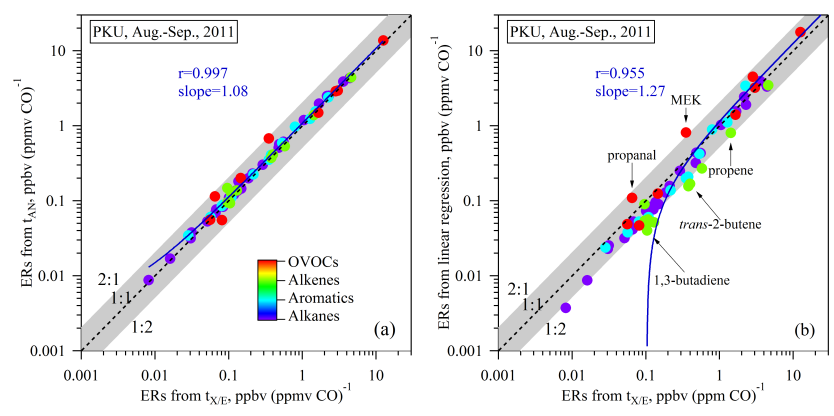

Figure 6. Emission ratios of individual VOC species calculated based on photochemical ages derived from $o$-xylene/ethylbenzene $\left(t_{\mathrm{X} / \mathrm{E}}\right)$ and compared with those obtained from (a) $2-\mathrm{BuONO}_{2} / n$ butane $\left(t_{\mathrm{AN}}\right)$ or (b) ODR linear regression of nighttime measurement data. Each data point represents an individual VOC species, which was colored VOC categories. The grey area represents the uncertainty range of $\pm 100 \%$. The black dashed line and the blue solid line represent the $1: 1$ line and the best fit, respectively.

were lower than the summertime values by a factor $\geq 2$, with the exception of acetylene, alkenes (e. g. ethene, propene, 1,3-butadiene), benzene, ethane, and formaldehyde. A recent study in French urban areas by Boynard et al. (2014) also found that benzene and some alkenes showed similar emission ratios relative to acetylene between summer and winter, whereas other NMHC species exhibited higher emission ratios in summer. This seasonal difference in emission ratios for most VOC species is possibly due to the seasonal variations in VOC sources. The relative contributions from combustion sources were possibly larger during winter because more fuels (e.g., coal, natural gas, and biofuel) were burned for heating, whereas evaporation processes (e.g., gasoline and solvent evaporation) contributed greater VOC emissions during summer owing to the high ambient temperatures. Unlike the complexity of VOC sources, $\mathrm{CO}$ is dominantly emitted from incomplete combustion processes. The seasonal profile of $\mathrm{CO}$ emissions in China reported by Zhang et al. (2009) suggested that CO exhibited higher emission strengths in heating months (November-March). The wintertime emission ratios for those VOC species mainly related to combustion processes (e.g., acetylene, ethene, and benzene) were close to the summertime emission ratios; however, the emission ratios for those VOC species influenced by noncombustion sources (e.g., propane, toluene, and acetone) tended to be higher in summer. Further discussion of the seasonal variations in VOC sources is presented in Sect. 3.4.2.

Figure $7 b-d$ compares the summertime emission ratios for individual VOC species at the PKU site during 2011 with those derived from online VOC measurements during 2010 (Yuan et al., 2012), 2008 (Wang et al., 2010), and 2005 (Liu et al., 2009) at the same site. The VOC emission ratios for the years 2010 and 2008 correlated well with those for 2011 ( $r=0.99$ for $2010, r=0.96$ for 2008), with linear regression slopes of $0.91 \pm 0.02$ and $1.15 \pm 0.05$, respectively. 

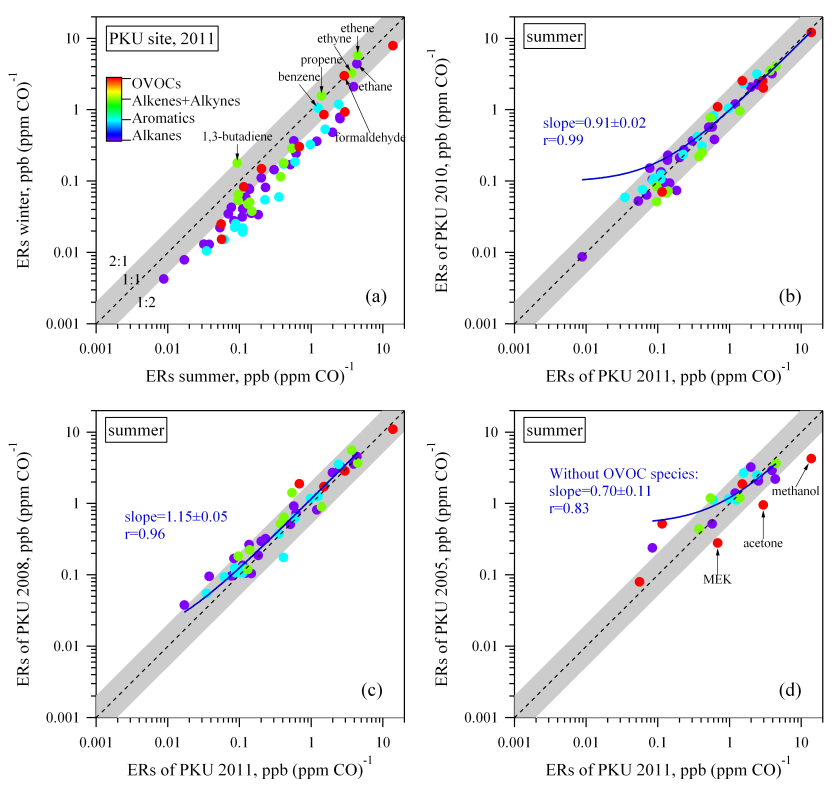

Figure 7. Comparison of emission ratios for VOC species obtained at the PKU site: (a) winter vs. summer, (b) 2010 vs. 2011, (c) 2008 vs. 2011, and (d) 2005 vs. 2011.

These results suggested the similarity of VOC compositions in 2008, 2010, and 2011. The NMHC emission ratios between 2005 and 2011 agreed within a factor of two $(r=0.83$, slope $=0.70 \pm 0.11)$. However, the emission ratios for methanol, acetone, and MEK in 2011 were larger than those for 2005 by a factor of approximately three. Based on the limited knowledge on OVOC sources, it is difficult to provide clear explanations for the increasing trend of the methanol and ketone emission ratio relative to $\mathrm{CO}$ between 2005 and 2011 at the PKU site. Further research on OVOC sources and emission trends is needed in future studies.

\subsubsection{Comparisons of VOC emission ratios on a spatial basis}

Figure 8a-c compares VOC emission ratios determined at the PKU site with those determined from the other three measurement data sets in China, including regional measurements at 27 sites in Beijing, measurements at urban sites in 47 cities (Wang et al., 2013), and online measurements from the Changdao site in Shandong Province (Yuan et al., 2013). The average VOC emission ratios for the 27 sites in Beijing and urban sites in 47 cities of China were calculated as the slopes of ODR linear fits for observations at 09:00 LT, whereas the VOC emission ratios for the Changdao site were calculated using the $[\mathrm{OH}] \Delta t$ method. The emission ratios for most VOC species between the PKU site and the 27 sites in Beijing agreed within a factor of two, with $r$ of 0.99 and linear regression slope of $0.91 \pm 0.02$ (Fig. 8a), suggesting that the VOC emission ratios determined at the PKU site could represent the urban mixture of VOC anthropogenic emissions in Beijing. The average summertime emission ratios for most NMHC species of the urban sites in 47 Chinese cities and the PKU site also showed good agreement (Fig. 8b), with $r$ of 0.94 and a slope of $0.83 \pm 0.04$, indicating the similarity of VOC composition at urban sites in China during summer. The wintertime emission ratios for most VOC species of the PKU site and the Changdao site agreed within a factor of two, with $r$ of 0.95 and a slope of $1.03 \pm 0.05$. The Changdao site in Shandong province is a rural receptor site, which mainly received emission from Shandong, Hebei, Beijing, and Tianjin provinces/municipalities in the North China Plain and Liaoning Province in the Northeastern Plain (Yuan et al., 2013). The consistency of wintertime VOC emission ratios between the PKU site and the Changdao site indicates the similarity of VOC composition in these regions during winter.

In Fig. 9, the VOC emission ratios determined at the PKU site are compared with those determined in northern American and European cities. The summertime emission ratios for most NMHC species of the PKU site and 28 cities of the United States (Baker et al., 2008) agreed within a factor of two, with the exception of $i$-butane and 1-butene, indicating the similarity of NMHC composition for urban emissions in Beijing and US cities. The summertime emission ratios for most alkene and aromatic species between the PKU site and Los Angles, US (Warneke et al., 2007; Borbon et al., 2013); New York city and Boston, US (Warneke et al., 2007); and Mexico City, Mexico (Bon et al., 2011) also agreed within a factor of two. However, the propane emission ratio in Mexico City was 16 times higher than that determined at the PKU site. One possible explanation for this discrepancy was that propane emission in Mexico City was likely dominated by leakage of LPG rather than combustion processes (Bon et al., 2011), and thus the emission ratio of propane relative to $\mathrm{CO}$ in Mexico City was much higher than that for Beijing and US cities. The summertime emission ratios of toluene and $i$-pentane in Paris, France, were 4-5 times higher than those determined at the PKU site. The possible causes for higher emission ratios of $\mathrm{C} 7-\mathrm{C} 9$ aromatics and $\mathrm{C} 4-\mathrm{C} 5$ alkanes in Paris have been discussed by Borbon et al. (2013) and could be due to the larger abundance of aromatics in gasoline and/or the higher hydrocarbon emissions from powered two wheelers (PTW) in Paris. OVOC emission ratios also exhibited large differences between Beijing, Los Angles, and Mexico City. The primary sources of OVOC species in urban areas are not well understood yet (Warneke et al., 2007). Besides vehicle exhaust, OVOC species can also be emitted from biomass burning (Yuan et al., 2010b), industrial processes (Kim et al., 2008), and residential coal combustion (Zhang and Smith, 1999). Much research has to be done on OVOC sources to explain the differences of OVOC emission ratios among these cities. 

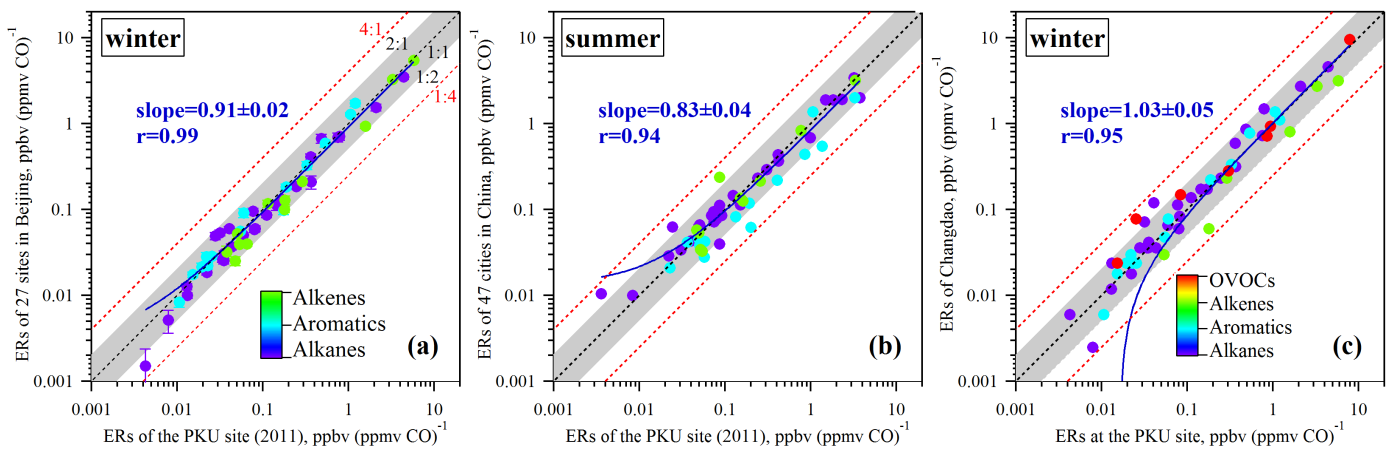

Figure 8. Comparisons of VOC emission ratios determined at the PKU site with those determined from (a) regional measurements at 27 sites in Beijing, (b) 47 cities in China (Wang et al., 2013), and (c) the Changdao site in China (Yuan et al., 2013).

\subsubsection{Estimation of VOC emissions in Beijing}

On the basis of the wintertime and summertime VOC emission ratios derived from measurements (see Supplement Table S5) and on the basis of the known CO emission in Beijing, the annual emissions for individual VOC species can be calculated using the following equation:

$$
\begin{aligned}
E_{\mathrm{VOC}, \mathrm{A}} & =\left(\mathrm{ER}_{\mathrm{VOC}, \mathrm{S}} \times \mathrm{E}_{\mathrm{CO}, \mathrm{S}}+\mathrm{ER}_{\mathrm{VOC}, \mathrm{W}} \times \mathrm{E}_{\mathrm{CO}, \mathrm{w}}\right) \\
& \times \mathrm{MW}_{\mathrm{VOC}} / \mathrm{MW}_{\mathrm{CO}},
\end{aligned}
$$

where $E_{\mathrm{VOC}, \mathrm{A}}\left(\mathrm{Gg} \mathrm{yr}^{-1}\right)$ is the annual emission for a particular VOC species; $E R_{\mathrm{VOC}, \mathrm{S}}$ and $\mathrm{ER}_{\mathrm{VOC}, \mathrm{W}}\left(\mathrm{ppbv}_{\mathrm{ppmv}}{ }^{-1}\right.$ ) are emission ratios of $\mathrm{VOC}$ species relative to $\mathrm{CO}$ in the summer and winter, respectively; $\mathrm{MW}_{\mathrm{VOC}}$ and $\mathrm{MW}_{\mathrm{CO}}$ are molecular weights of VOC and $\mathrm{CO}$, respectively; and $\mathrm{E}_{\mathrm{CO}, \mathrm{S}}$ and $\mathrm{E}_{\mathrm{CO}, \mathrm{W}}\left(\mathrm{Tg} \mathrm{yr}^{-1}\right)$ are emissions of $\mathrm{CO}$ during the summer (nonheating season, April-October) and winter (heating season, November-March), respectively. The magnitude of $\mathrm{CO}$ emissions is one important factor affecting the accuracy of calculated VOC emissions using Eq. (6). Several studies have reported the large uncertainties in bottom-up $\mathrm{CO}$ emission inventories (Streets et al., 2006; Carmichael et al., 2003). In this study, the CO emission estimated by Tang et al. (2013), which was validated using an inverse modeling approach based on online $\mathrm{CO}$ observations at 25 sites in Beijing, was used to calculate VOC emissions. The values for $\mathrm{E}_{\mathrm{CO}, \mathrm{S}}$ and $\mathrm{E}_{\mathrm{CO}, \mathrm{W}}$ were 2392 and $2280 \mathrm{Gg}$, respectively, according to the inverse model results from Tang et al. (2013) and the monthly variation in $\mathrm{CO}$ emission strengths from Zhang et al. (2009). The annual anthropogenic emissions for individual VOC species that were estimated using this method are listed in Supplement Table S5.

The annual emissions for individual VOC species derived from ambient measurements were compared with the speciated VOC emissions from the TRACE-P (Streets et al., 2003) and INTEX-B (Zhang et al., 2009) inventories (Fig. 10). Compared with results derived from measurements, the annual emissions of benzene, ketones, and aldehydes were possibly underestimated by $\geq 50 \%$ in the TRACE-P inventory, whereas the annual emissions for other VOC species agreed within a factor of two. The annual emissions of OVOC species in the INTEX-B inventory were also lower than the values derived from measurements by a factor of $\geq 2$. The underestimation for OVOC species in the bottom-up emission inventories may be due to the following reasons: (1) some emission sources for OVOC species were neglected or underestimated in the bottom-up inventories, or (2) the emission factors of OVOC species from some sources were underestimated. There is some support for each of these possibilities in the literature. De Gouw et al. (2005) and Warneke et al. (2007) suggested that the primary sources of OVOC species in urban areas were not yet well understood, but that they were unlikely to be automobile emissions. This is consistent with the first hypothesis. Meanwhile, Zavala et al. (2009) compared the OVOC emission factors derived from on-road measurements with those values applied to calculate vehicular emissions in Mexico City. It was found that the formaldehyde and acetaldehyde emission factors for calculating vehicular emissions seemed to be underestimated by factors of 2-3. This provides evidence for the second hypothesis. The emissions of some NMHC species in the INTEXB inventory also showed obvious discrepancies when compared to those derived from measurements, with the INTEXB inventory underestimating $\mathrm{C} 2-\mathrm{C} 4$ alkanes emissions but overestimating emissions of 1,3-butadiene and styrene. Previous studies found that $\mathrm{C} 2-\mathrm{C} 4$ alkanes can be emitted from natural gas leakage (Katzenstein et al., 2003), LPG usage (Blake and Rowland, 1995), and gasoline evaporation (Liu et al., 2008a). The lower emissions of $\mathrm{C} 2-\mathrm{C} 4$ alkanes in the INTEX-B inventory indicated that the VOC emissions from natural gas, LPG and gasoline usage might be underestimated. Petrochemical industrial sources were the most important contributor to 1,3-butadiene and styrene emissions in the INTEX-B inventory, with the relative contribution of 70 and $100 \%$, respectively. The higher 1,3-butadiene and styrene emissions in the INTEX-B inventory suggested that VOC emissions from petrochemical industrial sources might be overestimated. 

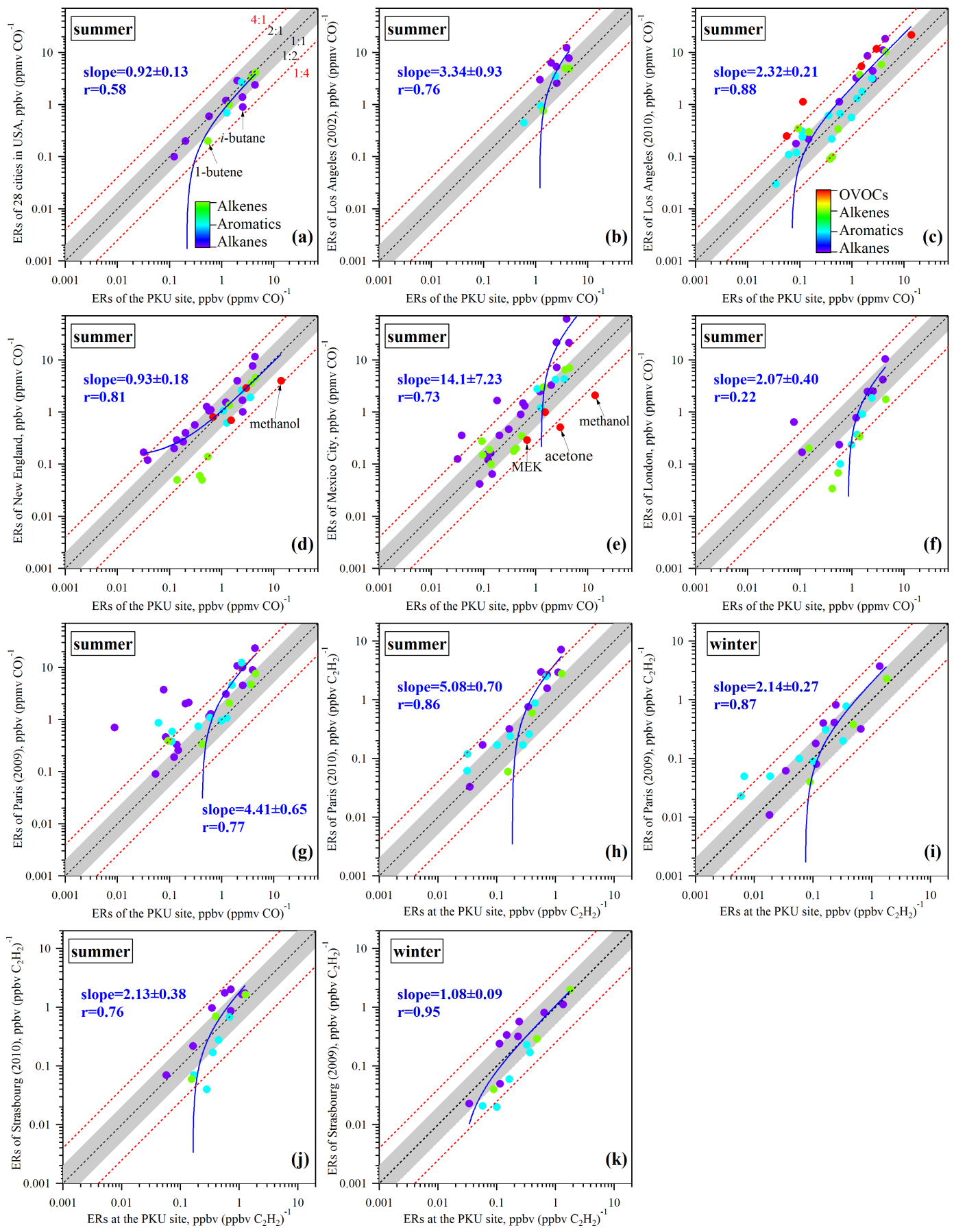

Figure 9. Comparisons of VOC emission ratios determined at the PKU site with those for (a) 28 US cities (Baker et al., 2008); (b) Los Angeles, US (Warneke et al., 2007; Borbon et al., 2013); (d) New York City and Boston, US (Warneke et al., 2007); (e) Mexico City, Mexico (Bon et al., 2011); (f) London, UK (McMeeking et al., 2012); (g-i) Paris, France (Borbon et al., 2013; Boynard et al., 2014); and (j-k) Strasbourg, France (Boynard et al., 2014).

Several model studies used field measurement data of $\mathrm{O}_{3}$ (Tang et al., 2011) and satellite observation data of glyoxal (Liu et al., 2012a) as constraints to validate VOC emissions in Beijing. The study by Tang et al. (2011) suggested that the emission strengths of total NMVOCs might be overestimated in the INTEX-B inventory, whereas Liu et al. (2012a) found anthropogenic aromatics might be underestimated in the INTEX-B inventory. In our study, the total emissions for measured VOC species (see Supplement Table S5) was estimated to be $419 \pm 201 \mathrm{Gg} \mathrm{yr}^{-1}$, slightly 

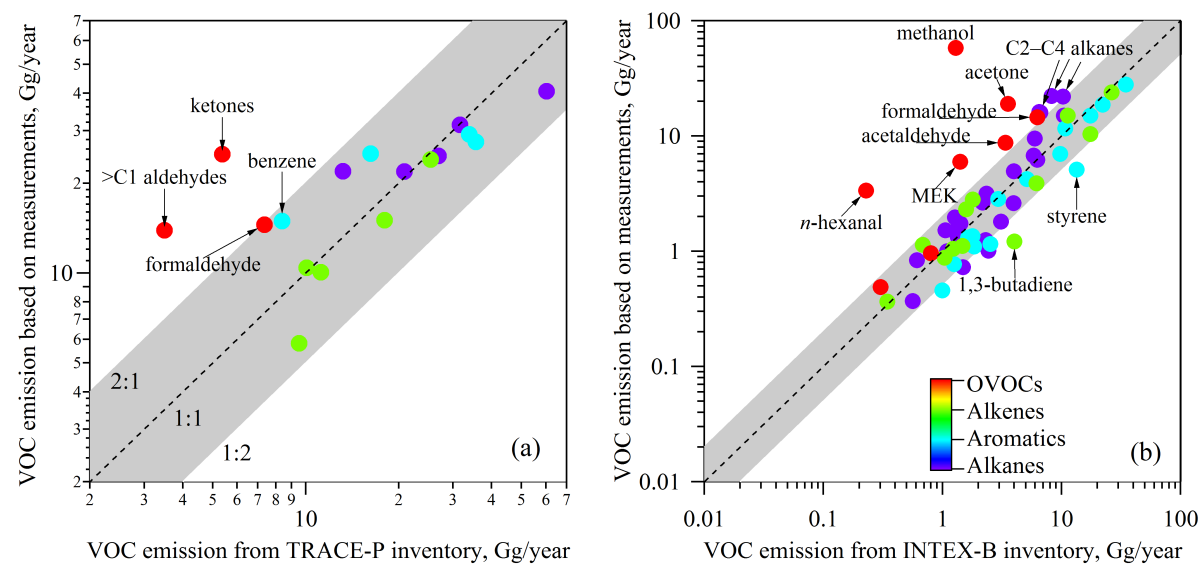

Figure 10. Comparison of the annual emissions of VOC species estimated based on measurements reported by the (a) TRACE-P (Streets et al., 2003) and (b) INTEX-B (Zhang et al., 2009) bottom-up emission inventories.

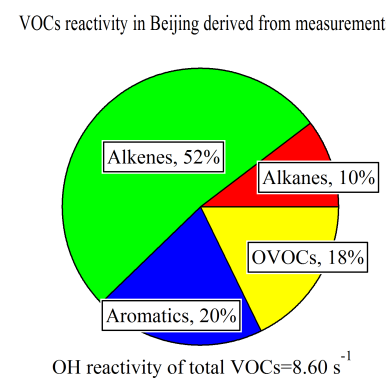

(a)

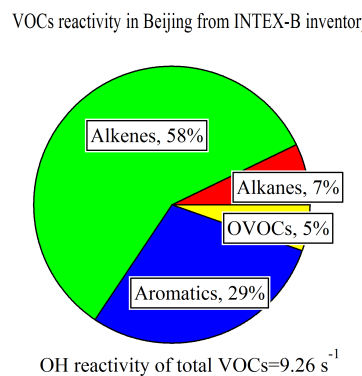

(b)

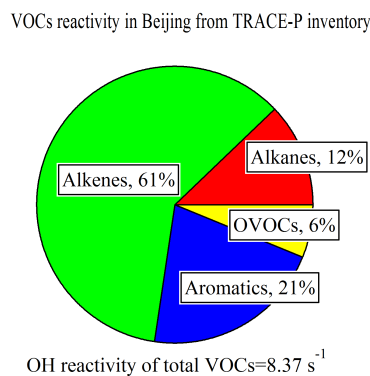

(c)

Figure 11. Comparison of the relative contributions of VOC groups to the total OH reactivity for measured VOC species in Beijing from (a) measurements, (b) the INTEX-B inventory (Zhang et al., 2009), and (c) the TRACE-P inventory (Streets et al., 2003). The OH reactivity for each VOC species was calculated as the product of its emission ratio, rate constant with $\mathrm{OH}\left(k_{\mathrm{OH}}\right)$, and an assumed $\mathrm{CO}$ mixing ratio (1.0 ppmv).

higher than the emissions provided by the INTEX-B inventory $\left(313 \mathrm{Gg} \mathrm{yr}^{-1}\right)$, but within the error bars. In addition, the calculated annual emissions for toluene and xylenes in our study agreed relatively well with values from the INTEXB inventory, with the relative differences of $\sim 20 \%$. These findings are inconsistent with the results from previous modeling studies by Tang et al. (2011) and Liu et al. (2012a). One explanation for this inconsistence is that these modeling studies used measurements of secondary pollutants (e.g., $\mathrm{O}_{3}$ and glyoxal) as constraints, and therefore they actually validated the capacity of VOC species to produce secondary pollutants rather than VOC emissions. The chemical formation of these secondary pollutants is not only influenced by VOC emissions but also their reaction mechanisms and/or efficiencies, and therefore it would be better to evaluate and validate VOC emissions based on VOC measurement data.

To further investigate the possible influences of VOC emissions uncertainty on $\mathrm{O}_{3}$ production modeling, the total $\mathrm{OH}$ reactivity for all measured VOC species $\left(\mathrm{s}^{-1}\right)$ was cal- culated using the following equation:

$$
\begin{aligned}
\text { total } \mathrm{OH} \text { reactivity } & =\sum \mathrm{OH}_{\text {reactivity }} \mathrm{VOC}_{\mathrm{VOC}} \\
& =\sum\left(\mathrm{ER}_{\mathrm{VOC}} \times \mathrm{k}_{\mathrm{VOC}} \times[\mathrm{CO}]\right),
\end{aligned}
$$

where $k_{\mathrm{VOC}}$ is the rate constant for the reaction of a particular VOC species with the $\mathrm{OH}$ radical. $\mathrm{ER}_{\text {VOC }}$ is the emission ratio of VOC. [CO] is the ambient mixing ratio of $\mathrm{CO}$, the value of which was assumed to be $1.0 \mathrm{ppmv}$ in this study. Figure 11 compares the total $\mathrm{OH}$ reactivity derived from measurements and that calculated based on the INTEX-B (Zhang et al., 2009) and TRACE-P (Streets et al., 2003) inventories. It can be found that the total $\mathrm{OH}$ reactivity from these three studies agreed relatively well, with values ranging from 8.4 to $9.3 \mathrm{~s}^{-1}$. However, the relative contributions of different VOC groups to the total $\mathrm{OH}$ reactivity showed significant differences among these studies. Compared with the results from measurements, the relative contributions of OVOC were significantly lower in the bottom-up emission inventories, whereas alkenes contributions were higher. This finding implies that if we were to use these two emission inventories as the input to a chemical transport model to 
simulate $\mathrm{O}_{3}$ production in Beijing, the model might predict ambient ozone levels well, but could underestimate the OVOC contribution to $\mathrm{O}_{3}$ production and overestimate the contribution of alkenes.

It should be noted that this "top-down" approach for the calculation of VOC emissions based on ambient measurements has several limitations and uncertainties. First, in this study, we used measurements carried out during AugustSeptember and December-January to derive VOC emission ratios during nonheating and heating seasons, respectively. This still limits the temporal representation of VOC measurement data relative to those continuous observations lasting more than one year. In addition, the VOC emission estimates in the TRACE-P and INTEX-B inventories were for the year 2000 and 2006, respectively, while the VOC observations in this study were conducted during 2009-2012. The uncertainty in the $\mathrm{CO}$ emission inventory is another important factor influencing the accuracy of calculated VOC emissions from measurements. The $\mathrm{CO}$ emission data set applied in this study was calculated using the inverse modeling method based on CO measurements (Tang et al., 2013), but the $\mathrm{CO}$ observations were only conducted during two weeks in July 2010. The temporal limitation of CO measurement data might increase the uncertainty of derived annual emission for $\mathrm{CO}$.

\subsection{VOC source apportionment}

In this section, the relative contributions of various VOC sources were calculated using the CMB model and compared with the results from emission inventories. First, the performance of CMB modeling in this study was summarized in Sect. 3.4.1. Second, the CMB results based on regional and online measurement data are presented to discuss the seasonal and spatial variation characteristics of NMHC sources in Beijing (Sect. 3.4.2). Third, the CMB results based on calculated NMHC emissions were compared with results based on measurement data to investigate the possible effect of chemistry on CMB modeling (Sect. 3.4.3). Finally, the VOC source structure obtained by the CMB modeling based on emissions was compared with that from bottom-up emission inventories to identify those VOC sources with large uncertainty.

\subsubsection{Performance of CMB modeling}

The performance of CMB modeling was usually checked using the following parameters: $R^{2}, \chi^{2}$, and $\%$ Conc. (EPA, 2013). (1) The $R^{2}$ is the fraction of variance in the measured concentrations that is explained by variance in the calculated concentrations. The $R^{2}$ value can vary from 0 to 1 and CMB modeling is satisfactory when $R^{2}$ is superior to 0.8 . (2) The $\chi^{2}$ value is the weighted sum of squares of differences between the calculated and measured concentrations for fitting species. The $\chi^{2}$ value equaling zero means that there is no difference between calculated and measured concentrations. The $\chi^{2}$ values in the range of $0-4$ are acceptable. (3) The \% Conc. value is the percentage of the sum of the model-calculated source contribution estimates to the measured mass concentration. This ratio should equal $100 \%$, but values ranging from 80 to $120 \%$ are acceptable. The CMB performance parameters for online VOC measurements at the PKU site and calculated NMHC emissions were at acceptable intervals, with $R^{2}$ in the range of $0.77-0.98, \chi^{2}$ in the range of $0.52-4.00$, and \% Conc. in the range of $82-109 \%$. However, $\chi^{2}$ values for four samples from regional VOC measurements were beyond the acceptable interval for $\chi^{2}$, with the maximum value of 6.02. These four samples were all collected at Rural sites (the BOW1 and BOW2 sites in Fig. 1) and their total NMHC concentrations ([NMHCs $]_{\text {sum }}$ ) were lower than $20 \mu \mathrm{g} \mathrm{cm}^{-3}$. The possible causes for the large $\chi^{2}$ values of $\mathrm{CMB}$ modeling at rural sites include the following: (1) aged background air was an important source for the measured VOCs at rural sites, but it was omitted from the CMB calculation; (2) the uncertainty of VOC measurement data at rural sites is greater, especially for those species with mixing ratios at pptv levels (e.g., cycloalkane and C7-C9 alkanes).

\subsubsection{Seasonal variation in NMHC sources}

Figure $12 \mathrm{a}-\mathrm{b}$ shows the average relative contributions of NMHC sources during summer and winter based on online measurement data obtained at the PKU site. In both seasons, gasoline vehicular exhaust was the largest source for measured total NMHC mixing ratios, with average relative contributions of $\sim 50 \%$. However, the relative contributions of gasoline evaporation, paint and solvent usage, and biogenic emission were significantly higher during summer, whereas the coal combustion contribution was larger during winter. The significant seasonal differences in NMHC sources at the PKU site could be explained by the following: (1) more coal is burned for heating during winter; (2) the high ambient temperatures in summer promote the evaporation of gasoline, paint and solvent emissions into the atmosphere; and (3) biogenic emissions are favored by the high light intensities and ambient temperatures during summer.

The NMHC source apportionment results from regional measurement data showed similar seasonal variation characteristics with those at the PKU site. Vehicular exhaust (i.e., the sum of Exhaust_G and Exhaust_D) was the predominant NMHC source in Beijing, with relative contributions in the range of 41-53\%, and it did not show a clear seasonal variation pattern. Biogenic emissions and gasoline evaporation exhibited larger contributions during summer (May-August), with values of $3-4 \%$ and $8-9 \%$, respectively (Fig. 13a). The relative contributions of paint and solvent utilization also showed higher values in summer, whereas industrial processing and coal combustion exhibited higher contributions in winter (Fig. 13b). Possible explanations for these seasonal variation patterns in different NMHC sources have 


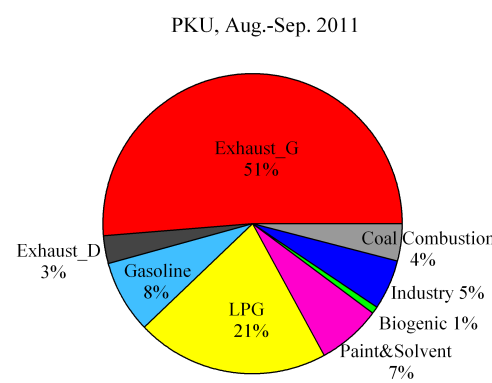

(a)

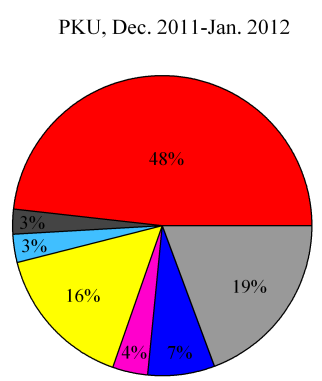

(b)

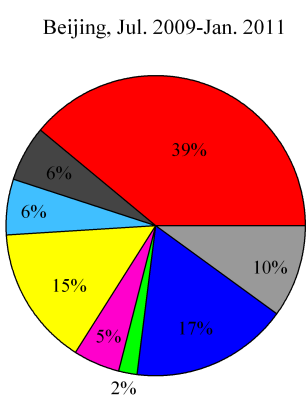

(c)

Figure 12. Comparison of the average relative contributions of different sources to ambient NMHCs at the PKU site during (a) summer, (b) winter, and (c) those for 27 sites in Beijing from July 2009 to January 2011.
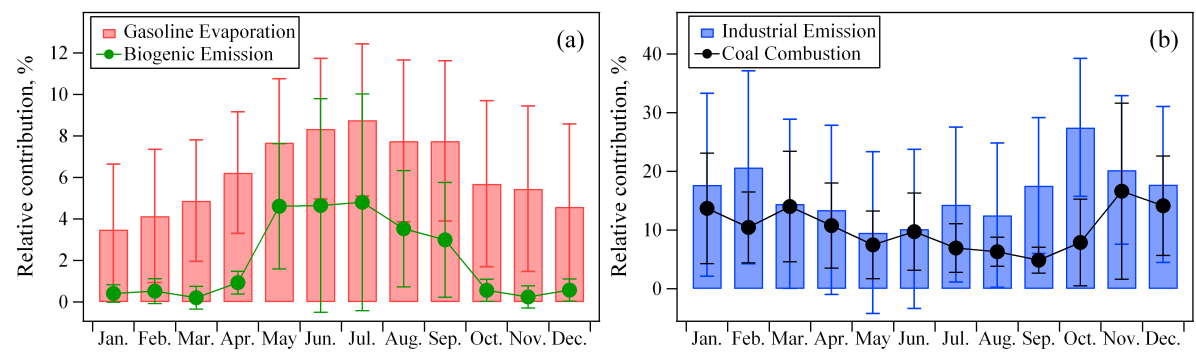

Figure 13. Monthly variations in the average relative contributions of (a) gasoline evaporation and biogenic emissions and (b) industrial emissions and coal combustion at 27 sites in Beijing. The error bars reflect one standard deviation from the average relative contributions.

been discussed based on the CMB results at the PKU site, except for industrial processing. The largest petrochemical company (Beijing Yanshan Petrochemical) is located in the southwest of Beijing (site I in Fig. 1). During the winter, the prevailing wind direction in Beijing is from the northwest or west, and thus this petrochemical company could affect the NMHC measurement data obtained at these sites in southern areas of Beijing. However, the influence of this petrochemical company would be less during summer because the prevailing wind is from the southeast and has relatively lower speeds, and thus fewer sites were affected by this industry.

\subsubsection{Spatial variation in NMHC sources}

Figure $12 \mathrm{c}$ shows the average relative contributions of various NMHC sources based on all regional observations conducted at the 27 sites from July 2009 to January 2011. The average relative contributions for industrial processing, diesel vehicle exhaust, and biogenic emissions from regional measurements were larger than the results at the PKU site. To further investigate the spatial distribution of NMHC sources, the relative contributions of each source were plotted on a map of Beijing. Figure 14a-d presents the contour maps of annual average relative contributions of gasoline vehicular exhaust, diesel vehicular exhaust, industrial processing, and biogenic emissions in Beijing. It can be found that the relative contributions of gasoline vehicle exhaust exhibited higher values (> 50\%) at Roadside (R1-R3) and Urban
(BI1-BI7) sites in the downtown area. One possible explanation for this finding is the high density of gasoline vehicles in central Beijing. In contrast to the spatial distribution of gasoline vehicular exhaust, diesel vehicular exhaust exhibited higher contributions (>10\%) at Suburban and Rural sites. This spatial distribution characteristic was likely associated with the greater use of diesel vehicles for agricultural activities in suburban and rural areas. The highest relative contributions of industrial processing were recorded at two Suburban_South sites (the BOS1 and BOS2 sites), close to the Beijing Development Area and Beijing Yanshan Petrochemical. For biogenic emissions, the largest contributions (>4\%) were found at suburban (Suburban_North and Suburban_South) and Rural sites with higher vegetative coverage. The relative contributions from the other three sources, including gasoline vaporization, paint and solvent utilization, and LPG usage, did not show clear spatial distribution characteristics.

\subsubsection{Comparison of CMB results based on measurement data and emissions}

To test the possible effect of chemistry on CMB modeling results, the annual emissions for each individual NMHC species derived from ambient measurements were applied as input data for the CMB modeling and compared with the $\mathrm{CMB}$ results based on measurement data. The fitting species for the CMB modeling based on emissions also involved 

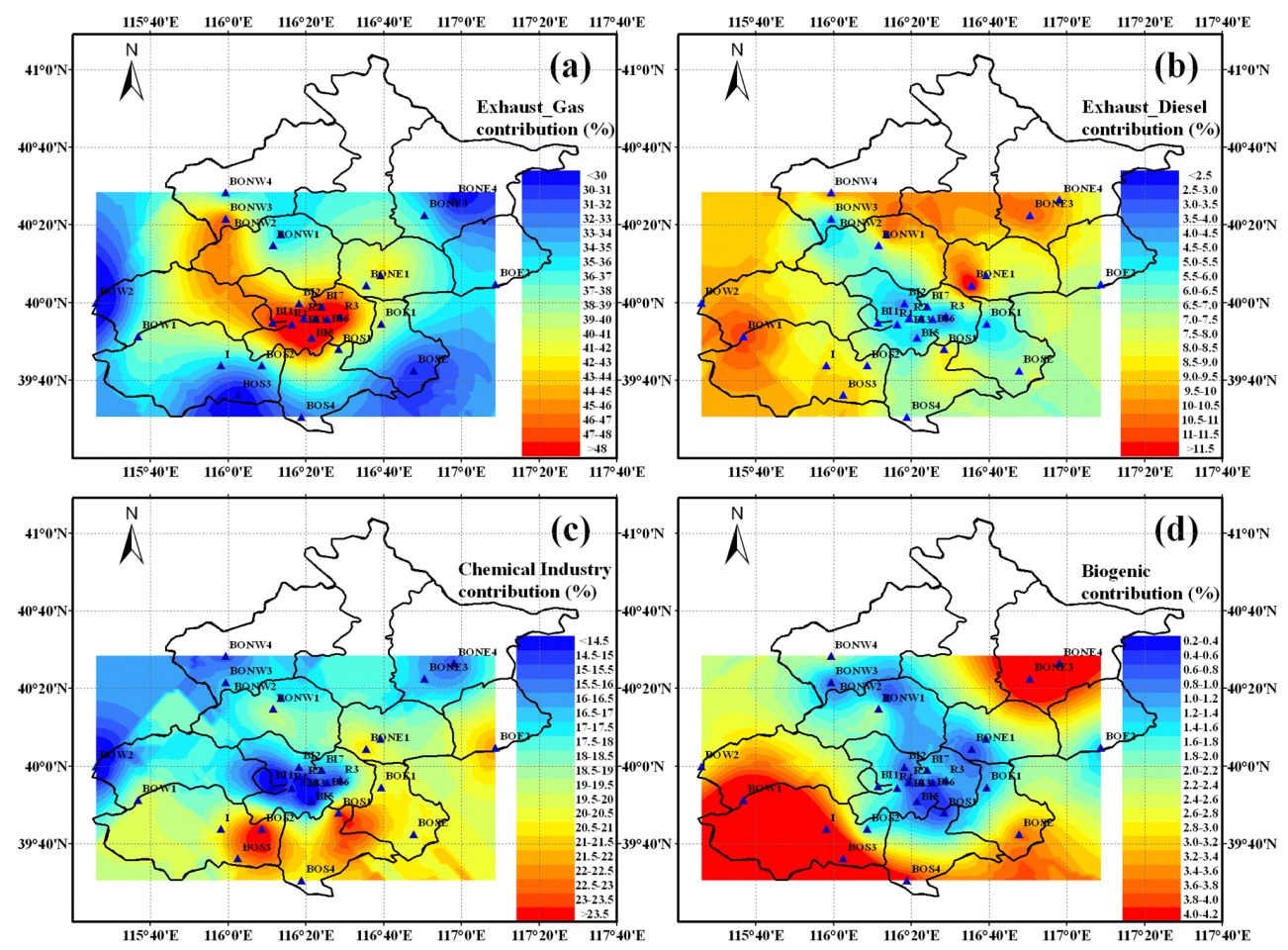

Figure 14. Spatial distributions of the relative contributions (\%) of (a) gasoline vehicle exhaust (Exhaust_Gas), (b) diesel vehicle exhaust (Exhaust_Diesel), (c) chemical industry, and (d) biogenic emissions to ambient NMHCs in Beijing.

some reactive NMHC species, such as ethene, propene, ethylbenzene, and xylenes (Supplement Table S3).

The relative contributions of each anthropogenic source to NMHC emission that are calculated by the CMB modeling based on measurement data (CMB_M) and emissions (CMB_E) were compared in Table 1. The relative contributions of gasoline vehicle exhaust, coal combustion, and gasoline evaporation calculated by the CMB_E were similar with results from $\mathrm{CMB}$ _M. However, the relative contributions of LPG usage and industrial processing from the CMB_E were lower than those for CMB_M, whereas paint and solvent utilization contribution from the CMB_E was higher. The discrepancy between CMB results based on emissions and measurement data suggests that the choice of nonreactive fitting species would possibly bias CMB modeling results. Therefore, the CMB results based on individual NMHC emissions were used for a comparison with VOC source structures given in emission inventories.

\subsubsection{Comparison with bottom-up emission inventories}

The CMB results based on emissions were compared with VOC source structures from bottom-up emission inventories (Bo et al., 2008; Wei et al., 2008; Zhang et al., 2009; Zhao et al., 2012). Both the CMB results and the emission inventories showed that vehicular emission was the most important NMVOC source in Beijing, with relative contributions of $40-55 \%$. The relative contribution for paint and solvent utilization obtained from the CMB model $(14 \%)$ was close to the value reported by Bo et al. (2008), but significantly lower than the value of $32 \%$ reported by Wei et al. (2008). Regarding industrial processing sources, its relative contribution estimated using the CMB model was $8 \%$, slightly lower than the values of $10-14 \%$ from emission inventories (Bo et al., 2008; Wei et al., 2008). The industry emissions in the INTEX-B and IPAC-NC inventories included VOC emissions from both industrial processing and industrial solvent utilization (Zhang et al., 2009; Zhao et al., 2012). In the INTEX-B inventory established by Zhang et al. (2009), residential solvent utilization was small compared with industrial solvent utilization, and therefore the relative contribution of industry emissions from Zhang et al. (2009) could be considered to correspond to the sum of contributions of industrial processing and paint and solvent utilization from the CMB model (Industry and Solvent). The relative contribution of the 'Industry and Solvent' source from the CMB model was $22 \%$, similar to the value of $24 \%$ reported by Bo et al. (2008), but significantly lower than the values of $41-$ $46 \%$ reported by Wei et al. (2008) and Zhang et al. (2009). The relative contribution of industry emission in the IPAC$\mathrm{NC}$ inventory was $3 \%$, significantly lower than the industrial processing contribution of $8 \%$ from the CMB model. Fossil fuel combustion contributions in emission inventories built by Wei et al. (2008) and Bo et al. (2008) showed large discrepancies. The coal combustion contribution obtained using 
the CMB model was $9 \%$, within the range of $3-15 \%$ given in these two emission inventories. The gasoline evaporation contribution from the CMB model was $4 \%$, slightly lower than the relative contribution of petroleum storage and transport $(6 \%)$ reported by Bo et al. (2008). In addition, the CMB results in this study suggested that LPG usage contributed $6 \%$ of NMHC emission in Beijing, but the relative contribution of LPG usage in Beijing has not been given in current emission inventories.

Several problems in existing VOC emission inventories were identified based on the above comparisons of VOC source structure in the $\mathrm{CMB}$ result in this study and different emission inventories: (1) there is no uniform standard regarding the classification of VOC sources for emission inventory establishment in China so far, which results in difficulty and uncertainty in the comparison of VOC source structures from different studies; (2) the relative contributions of paint and solvent utilization, industrial processing, fossil fuel combustion, and LPG usage in Beijing showed large discrepancies among different studies. Therefore, VOC emissions from these sources need to be reverified by future VOC emission inventories.

\section{Conclusions}

Ambient VOC and $\mathrm{CO}$ mixing ratios were measured in Beijing from July 2009 to January 2012. The monthly variations of those VOC ratios (e.g., toluene/ethene, $i$ pentane/ethene, and isoprene/1,3-butadiene) with similar atmospheric lifetimes indicated the seasonal difference in VOC sources in Beijing; while the seasonal and diurnal variations for the VOC ratios (e.g., ethene/acetylene and $o$ xylene / ethylbenzene) with similar sources but different reactivity suggested the important influence of photochemical processing on ambient VOC composition. The spatial distributions of measured VOC mixing ratios revealed a hotspot in southern suburban areas of Beijing, while the highest VOC emission strengths in current emission inventories were located in urban areas. All measured anthropogenic VOC species exhibited significant correlations with $\mathrm{CO}$, and the emissions ratios of individual VOC species relative to $\mathrm{CO}$ were then derived from ambient measurements using the photochemical age method. Based on the summertime and wintertime VOC emission ratios and the validated $\mathrm{CO}$ emission, the annual emissions for anthropogenic VOC species in Beijing were estimated and compared with speciated emissions given in emission inventories. The OVOC emissions calculated based on measurements were larger than those from existing inventories, whereas 1,3-butadiene and styrene emissions were higher in inventories. Vehicular exhaust was identified as the largest contributor to VOC emissions in Beijing using the CMB model, with a contribution of $49 \%$, which agreed well with the range of $40-51 \%$ given by current inventories. The contribution of paint and solvent uti- lization from the CMB was $14 \%$, close to the value from one inventory, but significantly lower than the value of $32 \%$ in another inventory. The coal combustion contribution obtained using the CMB model was $9 \%$, within the range of $3-15 \%$ in the existing emission inventories. In addition, the LPG contribution from the CMB model was $6 \%$, whereas the contribution of LPG usage to VOC emissions in Beijing was not given in current inventories. Using VOC measurement data to evaluate and validate the existing emission inventories is helpful in improving the prediction accuracy of air quality models. Additionally, identifying the reasons for the discrepancies between VOC emissions from measurement and inventories will help researchers to find out how to reduce the uncertainty of VOC inventories.

\section{The Supplement related to this article is available online at doi:10.5194/acp-14-5871-2014-supplement.}

Acknowledgements. This study was funded by the Natural Science Foundation for Outstanding Young Scholars (grant no. 41125018) and Natural Science Foundation key project (grant no. 41330635). The research is also supported by the Collaborative Innovation Center for Regional Environmental Quality.

Edited by: G. Frost

\section{References}

Atkinson, R. and Arey, J.: Atmospheric degradation of volatile organic compounds, Chem. Rev., 103, 4605-4638, doi:10.1021/cr0206420, 2003.

Atkinson, R., Baulch, D. L., Cox, R. A., Crowley, J. N., Hampson, R. F., Hynes, R. G., Jenkin, M. E., Rossi, M. J., Troe, J., and IUPAC Subcommittee: Evaluated kinetic and photochemical data for atmospheric chemistry: Volume II - gas phase reactions of organic species, Atmos. Chem. Phys., 6, 3625-4055, doi:10.5194/acp-6-3625-2006, 2006.

Baker, A. K., Beyersdorf, A. J., Doezema, L. A., Katzenstein, A., Meinardi, S., Simpson, I. J., Blake, D. R., and Rowland, F. S.: Measurements of nonmethane hydrocarbons in 28 United States cities, Atmos. Environ., 42, 170-182, doi:10.1016/j.atmosenv.2007.09.007, 2008.

Bertman, S. B., Roberts, J. M., Parrish, D. D., Buhr, M. P., Goldan, P. D., Kuster, W. C., Fehsenfeld, F. C., Montzka, S. A., and Westberg, H.: Evolution of alkyl nitrates with air mass age, J. Geophys. Res.-Atmos., 100, 22805-22813, doi:10.1029/95jd02030, 1995.

Blake, D. R. and Rowland, F. S.: Urban leakage of liquefied petroleum gas and its impact on Mexico City air quality, Science, 269, 953-956, doi:10.1126/science.269.5226.953, 1995.

Bo, Y., Cai, H., and Xie, S. D.: Spatial and temporal variation of historical anthropogenic NMVOCs emission inventories in China, Atmos. Chem. Phys., 8, 7297-7316, doi:10.5194/acp-8-72972008, 2008. 
Bon, D. M., Ulbrich, I. M., de Gouw, J. A., Warneke, C., Kuster, W. C., Alexander, M. L., Baker, A., Beyersdorf, A. J., Blake, D., Fall, R., Jimenez, J. L., Herndon, S. C., Huey, L. G., Knighton, W. B., Ortega, J., Springston, S., and Vargas, O.: Measurements of volatile organic compounds at a suburban ground site (T1) in Mexico City during the MILAGRO 2006 campaign: measurement comparison, emission ratios, and source attribution, Atmos. Chem. Phys., 11, 2399-2421, doi:10.5194/acp-11-23992011, 2011.

Borbon, A., Fontaine, H., Veillerot, M., Locoge, N., Galloo, J. C., and Guillermo, R.: An investigation into the traffic-related fraction of isoprene at an urban location, Atmos. Environ., 35, 37493760, doi:10.1016/S1352-2310(01)00170-4, 2001.

Borbon, A., Gilman, J. B., Kuster, W. C., Grand, N., Chevaillier, S., Colomb, A., Dolgorouky, C., Gros, V., Lopez, M., Sarda-Esteve, R., Holloway, J., Stutz, J., Petetin, H., McKeen, S., Beekmann, M., Warneke, C., Parrish, D. D., and de Gouw, J. A.: Emission ratios of anthropogenic volatile organic compounds in northern mid-latitude megacities: Observations versus emission inventories in Los Angeles and Paris, J. Geophys. Res.-Atmos., 118, 2041-2057, doi:10.1002/jgrd.50059, 2013.

Boynard, A., Borbon, A., Leonardis, T., Barletta, B., Meinardi, S., Blake, D. R., and Locoge, N.: Spatial and seasonal variability of measured anthropogenic non-methane hydrocarbons in urban atmospheres: Implication on emission ratios, Atmos. Environ., 82, 258-267, doi:10.1016/j.atmosenv.2013.09.039, 2014.

Carmichael, G. R., Tang, Y., Kurata, G., Uno, I., Streets, D., Woo, J. H., Huang, H., Yienger, J., Lefer, B., Shetter, R., Blake, D., Atlas, E., Fried, A., Apel, E., Eisele, F., Cantrell, C., Avery, M., Barrick, J., Sachse, G., Brune, W., Sandholm, S., Kondo, Y., Singh, H., Talbot, R., Bandy, A., Thorton, D., Clarke, A., and Heikes, B.: Regional-scale chemical transport modeling in support of the analysis of observations obtained during the TRACE-P experiment, J. Geophys. Res.-Atmos., 108, 8823, doi:10.1029/2002JD003117, 2003.

Chen, S. P., Liu, T. H., Chen, T. F., Yang, C. F. O., Wang, J. L., and Chang, J. S.: Diagnostic Modeling of PAMS VOC Observation, Environ. Sci. Technol., 44, 4635-4644, doi:10.1021/es903361r, 2010.

Coll, I., Rousseau, C., Barletta, B., Meinardi, S., and Blake, D. R.: Evaluation of an urban NMHC emission inventory by measurements and impact on CTM results, Atmos. Environ., 44, 3843 3855, doi:10.1016/j.atmosenv.2010.05.042, 2010.

de Gouw, J. A., Middlebrook, A. M., Warneke, C., Goldan, P. D., Kuster, W. C., Roberts, J. M., Fehsenfeld, F. C., Worsnop, D. R., Canagaratna, M. R., Pszenny, A. A. P., Keene, W. C., Marchewka, M., Bertman, S. B., and Bates, T. S.: Budget of organic carbon in a polluted atmosphere: Results from the New England Air Quality Study in 2002, J. Geophys. Res.-Atmos., 110, D16305, doi:10.1029/2004jd005623, 2005.

EPA-CMB8.2: Users Manual, http://www.epa.gov/ttn/scram/ receptor_cmb.htm, last access 6 June 2013.

Fu, T. M., Jacob, D. J., Palmer, P. I., Chance, K., Wang, Y. X. X., Barletta, B., Blake, D. R., Stanton, J. C., and Pilling, M. J.: Space-based formaldehyde measurements as constraints on volatile organic compound emissions in east and south Asia and implications for ozone, J. Geophys. Res.-Atmos., 112, D06312, doi:10.1029/2006jd007853, 2007.
Fuentes, J. D., Wang, D., Neumann, H. H., Gillespie, T. J., DenHartog, G., and Dann, T. F.: Ambient biogenic hydrocarbons and isoprene emissions from a mixed deciduous forest, J. Atmos. Chem., 25, 67-95, doi:10.1007/BF00053286, 1996.

Fujita, E. M., Watson, J. G., Chow, J. C., and Magliano, K. L.: Receptor model and emissions inventory source apportionments of non-methane organic gases in California's San Joaquin valley and San Francisco bay area, Atmos. Environ., 29, 3019-3035, doi:10.1016/1352-2310(95)00122-f, 1995.

Gaimoz, C., Sauvage, S., Gros, V., Herrmann, F., Williams, J., Locoge, N., Perrussel, O., Bonsang, B., d'Argouges, O., SardaEsteve, R., and Sciare, J.: Volatile organic compounds sources in Paris in spring 2007. Part II: source apportionment using positive matrix factorisation, Environ. Chem., 8, 91-103, doi:10.1071/en10067, 2011.

Heald, C. L., Jacob, D. J., Fiore, A. M., Emmons, L. K., Gille, J. C., Deeter, M. N., Warner, J., Edwards, D. P., Crawford, J. H., Hamlin, A. J., Sachse, G. W., Browell, E. V., Avery, M. A., Vay, S. A., Westberg, D. J., Blake, D. R., Singh, H. B., Sandholm, S. T., Talbot, R. W., and Fuelberg, H. E.: Asian outflow and transPacific transport of carbon monoxide and ozone pollution: An integrated satellite, aircraft, and model perspective, J. Geophys. Res.-Atmos., 108, 4804, doi:10.1029/2003jd003507, 2003.

Hsu, Y. K., VanCuren, T., Park, S., Jakober, C., Herner, J., FitzGibbon, M., Blake, D. R., and Parrish, D. D.: Methane emissions inventory verification in southern California, Atmos. Environ., 44, 1-7, doi:10.1016/j.atmosenv.2009.10.002, 2010.

Katzenstein, A. S., Doezema, L. A., Simpson, I. J., Balke, D. R., and Rowland, F. S.: Extensive regional atmospheric hydrocarbon pollution in the southwestern United States, P. Natl. Acad. Sci. USA, 100, 11975-11979, doi:10.1073/pnas.1635258100, 2003.

Kim, K.-H., Hong, Y.-J., Pal, R., Jeon, E.-C., Koo, Y.-S., and Sunwoo, Y.: Investigation of carbonyl compounds in air from various industrial emission sources, Chemosphere, 70, 807-820, doi:10.1016/j.chemosphere.2007.07.025, 2008

Klimont, Z., Streets, D. G., Gupta, S., Cofala, J., Fu, L. X., and Ichikawa, Y.: Anthropogenic emissions of non-methane volatile organic compounds in China, Atmos. Environ., 36, 1309-1322, doi:10.1016/s1352-2310(01)00529-5, 2002.

Kwok, E. S. C. and Atkinson, R.: Estimation of hydroxyl radical reaction-rate constants for gas-phase organic-compounds using a structure-reactivity relationship-an update, Atmos. Environ., 29, 1685-1695, doi:10.1016/1352-2310(95)00069-b, 1995.

Liu, Y., Shao, M., Fu, L. L., Lu, S. H., Zeng, L. M., and Tang, D. G.: Source profiles of volatile organic compounds (VOCs) measured in China: Part I, Atmos. Environ., 42, 6247-6260, doi:10.1016/j.atmosenv.2008.01.070, 2008a.

Liu, Ying, Shao, Min, Lu, Sihua, Chang, Chih-chung, Wang, JiaLin, and Chen, Gao: Volatile Organic Compound (VOC) measurements in the Pearl River Delta (PRD) region, China, Atmos. Chem. Phys., 8, 1531-1545, doi:10.5194/acp-8-1531-2008, 2008b.

Liu, Y., Shao, M., Kuster, W. C., Goldan, P. D., Li, X. H., Lu, S. H., and De Gouw, J. A.: Source identification of reactive hydrocarbons and oxygenated VOCs in the summertime in Beijing, Environ. Sci. Technol., 43, 75-81, doi:10.1021/es801716n, 2009.

Liu, Z., Wang, Y. H., Vrekoussis, M., Richter, A., Wittrock, F., Burrows, J. P., Shao, M., Chang, C. C., Liu, S. C., Wang, H. L., and Chen, C. H.: Exploring the missing source of gly- 
oxal (CHOCHO) over China, Geophys. Res. Lett., 39, L10812, doi:10.1029/2012g1051645, 2012a.

Liu, Z., Wang, Y., Gu, D., Zhao, C., Huey, L. G., Stickel, R., Liao, J., Shao, M., Zhu, T., Zeng, L., Amoroso, A., Costabile, F., Chang, C.-C., and Liu, S.-C.: Summertime photochemistry during CAREBeijing-2007: $\mathrm{RO}_{\mathrm{x}}$ budgets and $\mathrm{O}_{3}$ formation, Atmos. Chem. Phys., 12, 7737-7752, doi:10.5194/acp-12-77372012, 2012b.

Lu, K. D., Hofzumahaus, A., Holland, F., Bohn, B., Brauers, T., Fuchs, H., Hu, M., Häseler, R., Kita, K., Kondo, Y., Li, X., Lou, S. R., Oebel, A., Shao, M., Zeng, L. M., Wahner, A., Zhu, T., Zhang, Y. H., and Rohrer, F.: Missing $\mathrm{OH}$ source in a suburban environment near Beijing: observed and modelled $\mathrm{OH}$ and $\mathrm{HO}_{2}$ concentrations in summer 2006, Atmos. Chem. Phys., 13, $1057-$ 1080, doi:10.5194/acp-13-1057-2013, 2013.

McMeeking, G. R., Bart, M., Chazette, P., Haywood, J. M., Hopkins, J. R., McQuaid, J. B., Morgan, W. T., Raut, J.-C., Ryder, C. L., Savage, N., Turnbull, K., and Coe, H.: Airborne measurements of trace gases and aerosols over the London metropolitan region, Atmos. Chem. Phys., 12, 5163-5187, doi:10.5194/acp12-5163-2012, 2012

Monod, A., Sive, B. C., Avino, P., Chen, T., Blake, D. R., and Sherwood Rowland, F.: Monoaromatic compounds in ambient air of various cities: a focus on correlations between the xylenes and ethylbenzene, Atmos. Environ., 35, 135-149, doi:10.1016/s1352-2310(00)00274-0, 2001.

Niedojadlo, A., Becker, K. H., Kurtenbach, R., and Wiesen, P.: The contribution of traffic and solvent use to the total NMVOC emission in a German city derived from measurements and CMB modeling, Atmos. Environ., 41, 7108-7126, doi:10.1016/j.atmosenv.2007.04.056, 2007.

Ohara, T., Akimoto, H., Kurokawa, J., Horii, N., Yamaji, K., Yan, $\mathrm{X}$., and Hayasaka, T.: An Asian emission inventory of anthropogenic emission sources for the period 1980-2020, Atmos. Chem. Phys., 7, 4419-4444, doi:10.5194/acp-7-4419-2007, 2007.

Parrish, D. D.: Critical evaluation of US on-road vehicle emission inventories, Atmos. Environ., 40, 2288-2300, doi:10.1016/j.atmosenv.2005.11.033, 2006.

Seinfeld, J. H. and Pandis, S. N.: Atmospheric chemistry and physics: From air pollution to climate change, 2nd Edn, WileyInterscience, Hoboken, US, 2006.

Shao, M., Lu, S. H., Liu, Y., Xie, X., Chang, C. C., Huang, S., and Chen, Z. M.: Volatile organic compounds measured in summer in Beijing and their role in ground-level ozone formation, J. Geophys. Res.-Atmos., 114, D00g06, doi:10.1029/2008jd010863, 2009.

Shao, M., Huang, D., Gu, D., Lu, S., Chang, C., and Wang, J.: Estimate of anthropogenic halocarbon emission based on measured ratio relative to $\mathrm{CO}$ in the Pearl River Delta region, China, Atmos. Chem. Phys., 11, 5011-5025, doi:10.5194/acp-11-50112011, 2011.

Song, Y., Shao, M., Liu, Y., Lu, S. H., Kuster, W., Goldan, P., and Xie, S. D.: Source apportionment of ambient volatile organic compounds in Beijing, Environ. Sci. Technol., 41, 4348-4353, doi:10.1021/es0625982, 2007.

Streets, D. G., Bond, T. C., Carmichael, G. R., Fernandes, S. D., Fu, Q., He, D., Klimont, Z., Nelson, S. M., Tsai, N. Y., Wang, M. Q., Woo, J. H., and Yarber, K. F.: An inventory of gaseous and primary aerosol emissions in Asia in the year 2000, J. Geophys. Res.-Atmos., 108, 8809, doi:10.1029/2002jd003093, 2003.

Streets, D. G., Zhang, Q., Wang, L. T., He, K. B., Hao, J. M., Wu, Y., Tang, Y. H., and Carmichael, G. R.: Revisiting China's CO emissions after the Transport and Chemical Evolution over the Pacific (TRACE-P) mission: Synthesis of inventories, atmospheric modeling, and observations, J. Geophys. Res.-Atmos., 111, D14306, doi:10.1029/2006jd007118, 2006.

Takegawa, N., Miyakawa, T., Kuwata, M., Kondo, Y., Zhao, Y., Han, S., Kita, K., Miyazaki, Y., Deng, Z., Xiao, R., Hu, M., van Pinxteren, D., Herrmann, H., Hofzumahaus, A., Holland, F., Wahner, A., Blake, D. R., Sugimoto, N., and Zhu, T.: Variability of submicron aerosol observed at a rural site in Beijing in the summer of 2006, J. Geophys. Res.-Atmos., 114, D00G05, doi:10.1029/2008jd010857, 2009.

Tang, X., Wang, Z. F., Zhu, J., Gbaguidi, A. E., Wu, Q. Z., Li, J., and Zhu, T.: Sensitivity of ozone to precursor emissions in urban Beijing with a Monte Carlo scheme, Atmos. Environ., 44, 3833 3842, doi:10.1016/j.atmosenv.2010.06.026, 2010.

Tang, X., Zhu, J., Wang, Z. F., and Gbaguidi, A.: Improvement of ozone forecast over Beijing based on ensemble Kalman filter with simultaneous adjustment of initial conditions and emissions, Atmos. Chem. Phys., 11, 12901-12916, doi:10.5194/acp11-12901-2011, 2011.

Tang, X., Zhu, J., Wang, Z. F., Wang, M., Gbaguidi, A., Li, J., and Shao, M.: Inversion of $\mathrm{CO}$ emissions over Beijing and its surrounding areas with ensemble Kalman filter, Atmos. Environ., 81, 676-686, doi:10.1016/j.atmosenv.2013.08.051, 2013.

von Schneidemesser, E., Monks, P. S., and Plass-Duelmer, C.: Global comparison of VOC and CO observations in urban areas, Atmos. Environ., 44, 5053-5064, doi:10.1016/j.atmosenv.2010.09.010, 2010.

Wang, B., Shao, M., Lu, S. H., Yuan, B., Zhao, Y., Wang, M., Zhang, S. Q., and Wu, D.: Variation of ambient non-methane hydrocarbons in Beijing city in summer 2008, Atmos. Chem. Phys., 10, 5911-5923, doi:10.5194/acp-10-5911-2010, 2010.

Wang, M., Shao, M., Chen, W. T., Lu, S. H., Wang, C., Huang, D. K., Yuan, B., Zeng, L. M., and Zhao, Y.: Measurements of $\mathrm{C} 1-\mathrm{C} 4$ alkyl nitrates and their relationships with carbonyl compounds and $\mathrm{O}_{3}$ in Chinese cities, Atmos. Environ., 81, 389-398, doi:10.1016/j.atmosenv.2013.08.065, 2013.

Wang, X. S., Li, J. L., Zhang, Y. H., Xie, S. D., and Tang, X. Y.: Ozone source attribution during a severe photochemical smog episode in Beijing, China, Sci. China. Ser. B, 52, 1270-1280, doi:10.1007/s11426-009-0137-5, 2009.

Warneke, C., McKeen, S. A., de Gouw, J. A., Goldan, P. D., Kuster, W. C., Holloway, J. S., Williams, E. J., Lerner, B. M., Parrish, D. D., Trainer, M., Fehsenfeld, F. C., Kato, S., Atlas, E. L., Baker, A., and Blake, D. R.: Determination of urban volatile organic compound emission ratios and comparison with an emissions database, J. Geophys. Res.-Atmos., 112, D10S47, doi:10.1029/2006JD007930, 2007.

Wei, W., Wang, S., Chatani, S., Klimont, Z., Cofala, J., and Hao, J.: Emission and speciation of non-methane volatile organic compounds from anthropogenic sources in China, Atmos. Environ., 42, 4976-4988, doi:10.1016/j.atmosenv.2008.02.044, 2008.

Wu, L. L., Zeng, L. M., Yu, X. N., and Shao, M.: Determination of atmospheric $\mathrm{CO}$ and $\mathrm{CH} 4$ by GC-FID equipped with a low- 
pressure injector, Acta Sci. Circumstantiae, 30, 1766-1771, 2010 (in Chinese).

Yao, B., Vollmer, M. K., Zhou, L. X., Henne, S., Reimann, S., Li, P. C., Wenger, A., and Hill, M.: In-situ measurements of atmospheric hydrofluorocarbons (HFCs) and perfluorocarbons (PFCs) at the Shangdianzi regional background station, China, Atmos. Chem. Phys., 12, 10181-10193, doi:10.5194/acp-1210181-2012, 2012.

Yuan, B., Shao, M., Lu, S. H., and Wang, B.: Source profiles of volatile organic compounds associated with solvent use in Beijing, China, Atmos. Environ., 44, 1919-1926, doi:10.1016/j.atmosenv.2010.02.014, 2010a.

Yuan, B., Liu, Y., Shao, M., Lu, S. H., and Streets, D. G.: Biomass Burning Contributions to Ambient VOCs Species at a Receptor Site in the Pearl River Delta (PRD), China, Environ. Sci. Technol., 44, 4577-4582, doi:10.1021/es1003389, 2010b.

Yuan, B., Shao, M., de Gouw, J., Parrish, D. D., Lu, S., Wang, M., Zeng, L., Zhang, Q., Song, Y., Zhang, J., and Hu, M.: Volatile organic compounds (VOCs) in urban air: How chemistry affects the interpretation of positive matrix factorization (PMF) analysis, J. Geophys. Res.-Atmos., 117, D24302, doi:10.1029/2012JD018236, 2012.
Yuan, B., Hu, W. W., Shao, M., Wang, M., Chen, W. T., Lu, S. H., Zeng, L. M., and Hu, M.: VOC emissions, evolutions and contributions to SOA formation at a receptor site in eastern China, Atmos. Chem. Phys., 13, 8815-8832, doi:10.5194/acp-13-88152013, 2013.

Zavala, M., Herndon, S. C., Wood, E. C., Onasch, T. B., Knighton, W. B., Marr, L. C., Kolb, C. E., and Molina, L. T.: Evaluation of mobile emissions contributions to Mexico City's emissions inventory using on-road and cross-road emission measurements and ambient data, Atmos. Chem. Phys., 9, 6305-6317, doi:10.5194/acp-9-6305-2009, 2009.

Zhang, J. and Smith, K. R.: Emissions of Carbonyl Compounds from Various Cookstoves in China, Environ. Sci. Technol., 33, 2311-2320, doi:10.1021/es9812406, 1999.

Zhang, Q., Streets, D. G., Carmichael, G. R., He, K. B., Huo, H., Kannari, A., Klimont, Z., Park, I. S., Reddy, S., Fu, J. S., Chen, D., Duan, L., Lei, Y., Wang, L. T., and Yao, Z. L.: Asian emissions in 2006 for the NASA INTEX-B mission, Atmos. Chem. Phys., 9, 5131-5153, doi:10.5194/acp-9-5131-2009, 2009.

Zhao, B., Wang, P., Ma, J. Z., Zhu, S., Pozzer, A., and Li, W.: A high-resolution emission inventory of primary pollutants for the Huabei region, China, Atmos. Chem. Phys., 12, 481-501, doi:10.5194/acp-12-481-2012, 2012. 